\title{
JEWISH LAW, STATE, AND SOCIAL REALITY: PRENUPTIAL AGREEMENTS FOR THE PREVENTION OF DIVORCE REFUSAL IN ISRAEL AND THE UNITED STATES
}

\author{
AMIHAI RADZYNER
}

Professor at the Faculty of Law, Bar-Ilan University

\begin{abstract}
Rabbinical courts in Israel serve as official courts of the state, and state law provides that a Jewish couple can obtain a divorce only in these courts, and only strictly according to Jewish law. By contrast, in the Western world, especially the United States, which has the largest concentration of Jews outside of Israel, the Jewish halakha is not a matter of state law, and rabbinical courts have no official status. This article examines critically the common argument that for a Jew committed to the halakha, and in particular for a Jewish woman who wants to divorce her husband, a state-sponsored halakhic system is preferable to a voluntary one. This argument is considered in light of the main tool that has been proven to help American Jewish women who wish to obtain a halakhic divorce from husbands refusing to grant it: the prenuptial agreement. Many Jewish couples in the United States sign such an agreement, but only a few couples in Israel do so, primarily because of the opposition of the rabbinical courts in Israel to these agreements. The article examines the causes of this resistance, and offers reasons for the distinction that exists between the United States and Israel. It turns out that social and legal reality affect halakhic considerations, to the point where rabbis claim that what the halakha allows in the United States it prohibits in Israel. The last part of the article uses examples from the past to examine the possibility that social change in Israel will affect the rulings of rabbinical courts on this issue.
\end{abstract}

KEYWORDS: Jewish law, State of Israel, American Jewry, rabbinical courts, prenuptial agreements, divorce law

\section{INTRODUCTION: LECHATCHILAH AND BEDIAVAD IN DIVORCE ARRANGEMENTS}

There seems to be no other halakhic topic in which the decisors are as eager to reach a verdict lechatchilah (a priori) ${ }^{\mathrm{I}}$ as in divorce cases. Those who are familiar with halakhic literature in

I The terms lechatchilah (lit., a priori) and bediavad (lit., a posteriori) are used in the meaning ascribed by Rabbi Yosef Goldberg: "Whenever doubt arises in divorce law and the decisors are divided in their opinions, although in all prohibitions we follow the majority and the ruling is according to the majority, whether it is to be strict or lenient, in divorce law we must be concerned lechatchilah with the opinion that prohibits [even if it is the minority opinion]... . [In cases of] Bediavad, and in an emergency, we must follow the majority of the decisors, even if the minority opinion advocates strictness." Yosef Goldberg, Tivo Shel Get [The Nature of Divorce] 9 (2009). Emphases in citations have been added by the author, unless otherwise noted. 
general, and with rulings of the official rabbinical courts in Israel in particular, ${ }^{2}$ know how concerned many rabbinical judges (dayanim) and decisors are with any shred of doubt regarding the validity of the get (the divorce document in Jewish law, which must be presented by a husband to his wife to effectuate their divorce). The most common doubt is that the husband granted the get not of his free will, resulting in a get that is "coerced," which means invalid, leaving the woman married, with all the consequences this entails. The reluctance of many rabbinical judges to arrange a get whenever there is even the slightest fear that it may be coerced is well known are and requires no further evidence. Below I present some of the views held by rabbinical judges in Israeli courts concerning the policies of the system within which they operate. In an article that explains the view of the rabbinical court, one of the rabbinical judges from Tel-Aviv, Rabbi Zvi Yehuda Ben-Yaakov, stated that gittin should not be imposed except in extremely rare cases. ${ }^{3}$ He explained at length that the policy of rabbinical courts in Israel, following what, according to him, has been the custom in previous generations, is that whenever there is the slightest suspicion of coercion, or even a dispute as to whether or not to coerce, the court does not coerce.

Another judge in the rabbinical court system in Israel, Rabbi Yosef Goldberg, discussed extensively the subject of coerced get in three of his books. ${ }^{4}$ His position is that the court should avoid any suspicion of having coerced a divorce, even if it is a concern raised by a minority opinion among decisors, unless it is a state of "emergency." According to him,

In cases in which the decisors are divided whether or not to coerce the husband to divorce, and the majority opinion is that it is possible to coerce, lechatchila it is necessary to take the stricter position of the minority opinion and avoid coercing, but in an emergency (sheat hadehak) and in the case of igun [the possibility of chaining or anchoring the woman], according to Halakha, the ruling must follow the majority opinion and coerce.... The court should make every effort so that it is not necessary to resort to the permission granted in an emergency or in case of igun..$^{5}$

This common policy is criticized by Rabbi Shlomo Dichovsky. ${ }^{6}$ Rabbi Dichovsky describes the fear of many rabbinical judges to rule according to lenient and disputed opinions, and the conflicts he has had, including in the Supreme Rabbinical Court, with judges who disagreed with him fearing a coerced get. It is clear, therefore, that lechatchila the judges prefer to arrange a get that is valid by all accounts, or "glatt" (strictly kosher) in the words of Rabbi Dichovsky.7

2 The Israeli courts discussed in this article are the official courts of the State of Israel that operate by virtue of the law. All Jewish couples in Israel are subject to their jurisdiction in divorce cases. Nevertheless, there are also "private" courts operating in the ultra-Orthodox sector, apparently without any legal authority conferred by the state. These courts litigate also matters of divorce. See Amihai Radzyner, The Impact of Supreme Court Rulings on the Halakhic Status of the Official Rabbinical Courts in Israel, in Institutionalizing Rights and Religion: Competing SupremaCiES 224 (Leora Batnitzky \& Hanoch Dagan eds., 20I7) (discussing the relationship between these two systems).

3 Zvi Yehuda Ben-Yaakov, Peshara'O Din beHalikh Gerushin [Compromise or Law in the Divorce Process] (2010), http://tinyurl.com/mk4dycn.

4 E.g., Yosef Goldberg, Get Meuseh [Coerced Get] i 20-23 (2003); Goldberg, The Nature of Divorce, supra note I, ch. I-4; Yosef Goldberg, Elu she-Kofin le-Hotsi [Those Who Are Coerced to Divorce] ch. i (20I3).

5 Goldberg, Those Who Are Coerced, supra note 4, at 46-49. This position of Rabbi Goldberg has many implications for the ability to help women who are denied a divorce. For example, he argued that because of different positions put forth in halakhic rulings on the matter over the generations, it would never be possible to use the sanctions that Israeli law allows imposing on recalcitrant husbands. See GoldBerg, CoERCED GET, supra note 4, at 265-96.

6 Shlomo Dichovsky, Appropriate Judicial Practice in the Rabbinical Courts, 4 Milin Havivin I4I, I47-55 (2010).

7 Id. at $\mathrm{I} 44$. 
It is possible to bring other examples of rulings that adopt this policy, according to which one must seek a valid get lechatchila, even in difficult cases and even if according to most halakhic authorities it is possible to coerce the get $^{8}$ It is clear that this rigorous course of action appears in earlier halakhic sources, cited by Rabbis Zvi Yehuda Ben Yaakov and Yosef Goldberg. It is also possible to point out many cases in which judges acted based on lenient and controversial positions to make the recalcitrant husband grant a divorce. But I argue that the fact that the Israeli rabbinical court is a "monopoly," that is, the only institution in which Jewish citizens of the country can obtain a divorce, allows it to take a stricter stance than do courts in the United States and other states. ${ }^{9}$ In the opinion of various rabbinical judges, the legal situation in Israel requires a ruling lechatchila, whereas the reality in the Diaspora is one of bediavad or of emergency, which permits relying on lenient opinions.

I examine here the issue of prenuptial agreements used to avoid get refusal, which appears to be the most effective solution to the problem today. From this point of view, however, a significant distinction must be made between rabbinical courts in Israel and in the Diaspora, particularly in the United States. This distinction is the focus of this article. I show that prenuptial agreements are treated differently in the United States and Israel, and I argue that this is because of the different legal statuses of religious courts in these countries. Yet I conjecture that the strict policy of Israeli rabbinical courts on this issue is likely to change, based on other cases in which rabbinical courts have changed their policies to more lenient ones because of changes that were not under the control of the court.

\section{PRENUPTIAL AGREEMENTS: AMERICA AND ISRAEL}

In recent years, great effort has been made, resulting in considerable success, to persuade American Orthodox couples, especially modern ones, to sign a standard prenuptial agreement that ensures that the woman receives a get in case of separation. ${ }^{10}$ The common agreement is that of the Beth Din of America, ${ }^{\mathrm{II}}$ which I discuss in this article (the "American agreement"). The content

8 See, e.g., File No. I 84/1960 Supreme Rabbinical Court (Jerusalem), 4 PDR I64 (Israel). In this case, Rabbi Elyashiv cited many sources that allowed coercing the get, but he appeared to be seeking every way to avoid it, and eventually found such a way. The importance of this ruling stems from the status of Rabbi Elyashiv. It is difficult to overstate his enormous influence on the Israeli rabbinical court system and on many judges who regard themselves bound by his rulings. See, Avraham (Rami) Reiner, R. Yosef Shalom Elyashiv as a Halachic Decisor, 33 Modern JUDAISM, 260-300, 270 (2013). His influence is felt also in the area that is the subject of this article, as shown below.

9 As I show in previous articles, the monopoly of the rabbinical courts on matters of marriage and divorce in Israeli law raises many problems, even from the halakhic perspectives. The trend to adopt stringent rulings characterizes other issues for quite the same insights that will be shown below. See, e.g, Amihai Radzyner, Problematic Halakha: Creative Halakbic Rulings in Israeli Rabbinical Courts, 20 Jewish Law Annual 103 (2013); Radzyner, Annulment of Divorce in Israeli Rabbinical Courts, 23 Jewish Law Association Studies 193 (2013).

Io Much has been written about this agreement, about its transformations, and about its halakhic foundations. See, e.g., Kenneth Auman \& Basil Herring eds., The Prenuptial Agreement: Halakhic and Pastoral Considerations (I996); Rachel Levmore, Min`i 'Enayikh mi-Dim'ah [Restrain Your Eyes From Tears] 53-67 (2009); Levmore, Rabbinic Responses in Favor of Prenuptial Agreements, 42 TRADITION 29 (2009); Levmore, Preventing Get Refusal: From the Beth Din of America to the Israeli Agreement for Mutual Respect, http://tinyurl.com/ z4g2ywq; Mordechai Willig, The Prenuptial Agreement: Recent Developments, I Journal of THE Beth DiN OF AMERICA I2 (2OI2). A great deal of information is available on sites devoted to encouraging signing the agreement: The Organization for the Resolution of Agunot (ORA), www.getora.org/\#!the-prenup/ctzx (last visited May I4, 20I 8); The Prenup, www.theprenup.org (last visited May I4, 2018).

i I The Prenup, Prenup Forms, www.theprenup.org/prenupforms.html (last visited May I4, 20I8). 
and objectives of the agreement are described by the Beth Din of America. ${ }^{\mathrm{I2}}$ Briefly, the agreement requires the parties to appear before the court and obligates the husband to pay his wife spousal support in the amount of \$I5O per day, from the day of the separation until the get is granted (unless the woman herself refuses to cooperate with the Beth Din of America). The agreement is designed to place considerable financial pressure on the husband to cause him to grant the divorce.

The agreement won support from the heads of the yeshiva at Yeshiva University, and of important halakhic decisors and judges, especially from Israel. ${ }^{13}$ In 2006, the largest rabbinical organization in North America, the Rabbinical Council of America, decreed that its members must ensure that such an agreement exists when they conduct a marriage ceremony. ${ }^{14}$ Members of the Beth Din of America report that the agreement has a roo percent rate of success: it led to quick divorce settlements in most cases, and prevented get refusal even in the few cases in which the husband who had signed the agreement initially refused to grant the divorce. ${ }^{15}$ In other words, it is reasonable to assume that it solved cases in which protracted get refusal may have ensued on the part of the husband, had he not signed the agreement.

In recent years, efforts are under way in Israel as well to motivate couples to sign a prenuptial agreement to prevent get refusal. The most common agreement is known as a "Mutual Respect Agreement." ${ }^{16}$ Recently it has been adopted, with minor variations, by the rabbis of the Tzohar organization, who promote it under the name "Agreement of Love" (in the discussion below I do not distinguish between them and refer to both as the "Israeli agreement"). ${ }^{17}$ As it is possible to see from the comparison of the two agreements, in both countries the mechanism is based on the obligation undertaken by the husband to pay a high spousal support from the time of separation until the end of the marriage. Note, however, that the amounts mentioned in the Israeli agreement are significantly smaller in real terms than those in the American agreement. ${ }^{18}$

I2 The Prenup, theprenup.org/whatdoes.html (last visited My I4, 2018).

I3 The Prenup, Rabinic Endorsements, www.theprenup.org/rabbinic.html (last visited May I4, 2018).

i4 Rabbinical Council of America, Use of Prenuptial Agreement, www.rabbis.org/news/article.cfm?id=100772 (last visited May i4, 20I 8). See also, Rabbinical Council of America, 20 i6 Resolution, http://www.rabbis.org/news/ article.cfm?id=I05863 (last visited May I4, 2018).

I5 Levmore, Min'i, supra note Io at 75-76, n. 203-04; Shlomo Weissmann, Ending the Agunah Problem as We Know It, Orthodox Union (August 23, 20I2), tinyurl.com/hd2v2yj; Dovid Lichtenstein, The Agunah Crisis: What, If Anything, Can Be Done? Is a Prenuptial Agreement Halachically Condoned?, YUTORAH ONLINE (Jan. 24, 2015), http://tinyurl.com/zjy $3 \mathrm{hn}_{4}$, minute 38 (comments of Yona Reiss); Beverly Siegel, Sign on the Dotted Line, TABLET (March 6, 20I 5), tinyurl.com/j8zzjb8.

I6 The agreement underwent several transformations, and I refer here only to its final version. The Hebrew and English versions of the agreement, as well as references to articles that explain the halakhic and legal basis for it, can be found at Young Israel, Iyim.org.il/prenup/ (last visited May I4, 20I 8). It is noted on the site that the English translation has been done "in cooperation with Rabbi Yonah Reiss and Rabbi Prof. Michael Broyde." In other words, members of the Beth Din of America, the source of the American agreement, did not object to using a similar agreement in Israel. Much has been written about this agreement as well, for example, LeVmore, Min's, supra note Io, at I67-209; Levmore, Get Refusal and the Agreement for Mutual Respect: Israel Today, 9 Н̈акIRAH I73 (20I0).

I7 The agreement in English can be downloaded at Tzohar, Tzohar Prenuptial Agreement tinyurl.com/j5lo5n2 (last visited May I4, 20I8). For further details on the agreement, and its halakhic basis, including a discussion of the allegations that may be raised against it, see Elisha Aviner \& Avraham Stav, "Heskem me-Ahavah": haReka vehaYesod haHilkhati ["Agreement of Love”: Background and Halakhic Basis], 38 TzoHar 7I (20I5); David Stav \& Avraham Stav, Heskemey Kedam-Nissuin: Diyun Ra'ayoni Ekroni [Prenuptial Agreements: A Conceptual-Axiomatic Investigation], 38 TzOHAR 95 (2015).

I 8 As noted, the American agreement stipulates a payment of $\$ 4,500$ per month; the average wage in the United States in 2015 stood at $\$ 4,008$ per month. Social Security Administration, National Average Wage Index, www.ssa.gov/oact/cola/AWI.html (last visited May I4, 20I8). In Israel, the Agreement stipulates a payment of 
The Israeli agreement differs from its American counterpart in that it lacks a clause requiring the parties to appear in court, because Israeli law already obligates them to do so. Another difference is that alongside the husband's undertaking there is an identical undertaking on the part of the wife to pay spousal support to the husband following the separation, because in Israel, where divorce is always halakhic, a situation can arise in which the man is prevented from marrying according to state law if his wife refuses to accept the get. ${ }^{\text {I9 }}$

It appears, however, that the most significant difference between the two agreements does not lie in their formulation but in the chances that they can indeed help women who have been refused a get. In Israel, contrary to the United States, this likelihood is rather low, which is one reason why the number of signatories of these agreements is also relatively small. ${ }^{20}$ The simple fact is that in Israel the advocates of the agreement cannot make a claim similar to the one that appears in bold letters on the landing page of the Beth Din of America agreement site: "The Prenup is the single most effective solution to the Agunah problem." ${ }^{21}$ Indeed, there is no similar claim on the sites of the two Israeli agreements. Although the benefits of the agreement are explained, there is no statement that would lead the couple to believe that the agreement promises to prevent the suffering caused by get refusal.

The reason for this difference is that the rabbinical organizations and the large rabbinical courts in North America stand behind the American agreement; they are the ones who encourage the couples to sign the agreement, and they commit to making every effort to arrange a get even (and perhaps especially) in cases in which the agreement is activated and the husband grants the get because of the economic pressure exerted on him. Reality shows that this is indeed what happens. By contrast, in Israel the agreement is not backed by a court that is committed to enforcing it. ${ }^{22}$ On the contrary, the messages emanating from the official rabbinical courts in Israel, which are the only institutions where Jewish couples can divorce, are hostile to the agreement. To the best of my knowledge, no rabbinical judge in Israel has published an article or made a public statement in

NIS 6,000 per month or 50 percent of the net wage, which in 2015 stood at NIS 9,590, Central BurEau OF STATISTICS, tinyurl.com/zxuoprh (last visited May I4, 20I8). I believe that distinguishing between the wages of men and women and addressing various taxation aspects does not change the big picture. In any case, it seems that it is not easy to specify an American amount as a reasonable amount for the spousal support payment that would not create a significant difficulty for the average man. See Shalom Dover Levin, Heskem Kedam-Nissuin [Prenuptial Agreement] $\mathbb{S}$ 5, CHABAD - Lubavitch Library (2015), http://tinyurl.com/jn22rdn.

I9 By contrast, in the United States, if a man obtains a civil divorce but his wife refuses to accept her get, he can obtain halakhic permission to remarry. See, for example, Rabbi Moshe Feinstein, Responsa Igrot Moshe, Even HaEzer 2:2 (1964); David J. Bleich, A Suggested Antenuptial Agreement: A Proposal in the Wake of Avitzur, 7 Journal of Halacha AND CONTEMPORARY SoCIETY 25, 27 (I984).

20 Even in the absence of accurate data on the number of couples that have signed such agreements, it is reasonable to assume that the numbers for the United States are much larger, despite the fact that the number of couples that marry according to Orthodox Jewish law is much smaller than its counterpart in Israel, where such marriage is the only one recognized for Jewish couples. It is certain that in Israel no rabbinical organization has a requirement that corresponds to the demand of the Rabbinical Council of America that its members perform marriage ceremonies only after the couple has signed a prenuptial agreement. As far as it is possible to determine, in Israel, even among the more modern sectors of Orthodoxy, the signing of such agreements is still not commonplace, although it has increased over the years.

2 I The Prenup, supra note Io.

22 Naturally, there may be cases in which the agreement helps by its sheer existence, i.e., the spouse is afraid of refusing the get because of the existence of the agreement, so there is no need to enforce it, and the rabbinical court is unaware of its existence. But the number of these cases cannot be known. The main force of the agreement is felt when it must be activated, and therefore, the position of the rabbinical court toward it is a significant factor that distinguishes between Israel and the United States. Moreover, the understanding of the husband that the court will refuse to arrange the get if the agreement is activated is liable to remove the fear of its enforcement. 
support of the Mutual Respect Agreement or the Agreement of Love. ${ }^{23}$ By contrast, there is an abundance of harsh criticism of these agreements on the part of rabbinical judges, including statements that it is not possible to arrange a valid get if such an agreement is in force.

The official systems in Israel that are engaged in arranging marriages and divorces do not encourage the signing of such agreements. The assumption of several members of the Knesset and of former justice minister Tzipi Livni, that the agreement may be an effective solution to the problem of get refusal, except that the public is not sufficiently aware of it, resulted in several legislative proposals during the I9th Knesset (2013-20I4), aimed at encouraging the signing of such agreements. ${ }^{24}$ The bills were opposed by Chief Rabbi David Lau ${ }^{25}$ and by organizations established to preserve the status of the rabbinate, which claimed, and rightly so, that according to many rabbinical judges the agreement is contrary to Jewish law and it is liable to result in coerced gittin. ${ }^{26}$ As a compromise, it has been decided to establish a public commission to discuss the issue, but it was dispersed without having reached any conclusions ${ }^{27}$ when the I 9 th Knesset was dissolved. As far as I know, no rabbinical judge came before the commission in support of such agreement, but the commission did hear the trenchant opinion against the agreements of a veteran rabbinical judge, Rabbi Binyamin Be'eri. According to publications, this opinion was presented to the commission at the request of the Chief Rabbinical Council. Rabbi Be'eri rejected outright the very creation of such agreements. ${ }^{28}$ Apparently, there have been cases in which couples that have signed the agreement on their own initiative were refused by the official authorities that register marriages to approve these agreements, based on halakhic opposition to their existence. ${ }^{29}$

In sum, whereas in the United States the agreement is touted as a great success and backed by numerous rabbinical recommendations stipulating that no marriage should be

23 Even if we assume that there are rabbinical judges who support the agreement and for various reasons are afraid to advertise their position, in a reality in which the rabbinical court is an official state court, it is easy to understand that the spouse that files for divorce cannot demand to have their case heard by a specific rabbinical judge, just as litigants in civil court cannot choose the judge who will hear their cases. By contrast, in the United States, the parties can choose the court, but the signing of the agreement requires them to appear before a court that favors the agreement.

24 For example, Hatsa'at Hok leTikun Pekudat haNissuin vehaGerushin (Rishum) (Heskem Kedam-Nissuin) 5775-2014 [Marriage and Divorce (Registration) Order (Amendment) Bill] (Dec. 3, 2014), at 466, tinyurl.com/ jjhb82n (Israel).

25 Yonatan Orich, haRav Lau: Lamah Livni Mita'revet beInyaney haRabannut? [Rabbi Lau: Why Does Livni Intervene in Matters of the Rabbinate?], NRG (June 9, 20I4, I0:5 I a.m.), tinyurl.com/hvoxgs9; see also, Chief Rabbinical Council, Meeting No. 8 of June 9, 20I4, Israel Chief Rabinate, tinyurl.com/y7nxy 44s.

26 For example, Shanuy bemahloket: Heskem Kedam-Nissuin [Controversial: Pre-Nuptial Agreement], AYIN PЕКUНА, tinyurl.com/hafkuhg; Libah Center, haTsiyonut haDatit: Amitot Yesod [Religious Zionism: Basic Truths], at I8, tinyurl.com/zo6wjqw.

27 "Appeal to the Public to Present Positions and Proposals to a Public Committee," Ministry of Religious Services, June 26,2014 , on file with the author.

28 Avraham Haim Sherman, Heskem Kedam-haNissuin Shel Rabaney Tzohar: Behinatam leOr Ekronot haHalakha uMishpatey haTorah [Prenuptial Agreements of Tzohar Rabbis: Their Examination Based on The Principles and Laws of Halakha and Torah Law], in Kenes HADAYANim, 5775 [CONFERENCE OF RAbBinical Judges - 20i 5], 363 , 380 (Shimon Yacobi \& Yechiel Chaim Freimann eds., 20I6).

29 Israeli law requires that the prenuptial agreement be formally approved; the most convenient option is to have it approved by the Registrar of Marriage, who is usually a local rabbi or employee of the local religious council. About these problematic cases, see, for example, Rashamey Nissuin Mesarvim leAsher Heskemey Trom Nissuin, beNigud laHok [Marriage Officials Refuse to Approve Prenuptial Agreements, Contrary to the Law], KNESSET (April 29, 2013), tinyurl.com/hth5gjm; Yair Etinger, kesheDatiyim Rotsim Heskem Kedam-Nissuin [When Religious People Want a Prenuptial Agreement], HaAretz (Sept. I4, 2012, I0:02 p.m.), tinyurl.com/ jv3a4us. 
contracted without signing it, in Israel its rate of success is much smaller. What is the explanation for this?

\section{“PRENUPTIAL AGREEMENTS": IS IT KOSHER? DEPENDS ON WHERE}

It is clear that some rabbis in Israel $3^{\circ}$ and in the United States ${ }^{3 \mathrm{I}}$ oppose the current US agreement and therefore the Israeli agreement, which is similar to it, as well. The key halakhic argument against the agreement is fear of a coerced get. But there is a second group of rabbis who are opposed to the signing of the Israeli agreement, but openly or tacitly support the American one, or do not express outright opposition to it. In the present article, I try to understand the considerations of members of the second group. Understanding their position is important because among these rabbis of significant stature are important and recognized judges; if these rabbis treated the Israeli agreement the same way they treat its American counterpart, it would make its acceptance much easier, and it would make it impossible to argue that it is invalid in part because "none of the important judges and decisors added his signature to approve this agreement." 32

The site of the American agreement lists the approval of four important Israeli rabbis: 33 Rabbi Ovadia Yosef, Rabbi Chaim Zimbalist, Rabbi Asher Weiss,34 and Rabbi Zalman Nehemiah

30 The two most significant figures appear to be Rabbi Yosef Shalom Elyashiv and Rabbi Moshe Sternbuch. See, e.g., Zvi Gartner, beDin Mezonot deMegureshet veEyna Megureshet - leTakanat Agunot [About the Spousal Support Law of "Divorced and Not Divorced Women"], 90 Moriah 76 (I988) (discussing Rabbi Elyashiv's opinion); Chaim Lev, Haredi Rabbis Come Out against Prenups, Arutz SHEva (June 5, 20I6), http://tinyurl.com/kn2wdfm. Rabbi Sternbuch's letter can be found at Eli Schnieder, Rabbi Sternbuch: Prenup Is the Destruction of Religion, Kol Hazman, www.kolhazman.co.il/53 I 84 . Note that Rabbi Elyashiv's opinion that forbids arranging a get if the husband undertook a high monetary obligation in case he refuses to grant the get, has appeared already in a ruling of the Supreme Rabbinical Court in I956. Appeal 47/I956, 2 PDR, 9, I4. This position serves as a key source for the opponents of the agreement. For example, Uriel Lavi, Shelosha Tikkunim la "Heskem leKavod Hadadi" [Three Amendments to the "Mutual Respect Agreement"], 20 TzoHar I05, 108-09 (2005); Pinchas Shapira, Kunteres Kedushat haNissuin: Odot Heskemey Trom Nissuin [Pamphlet on the Sanctity of Marriage: About Prenuptial Agreements], 6 (2015); David Yoseph Mescheloff, HeskeminKedam Nissuin [Prenuptial Agreements] 2I Techumin 288, 304 (200I).

3 I Two prominent figures are Rabbi Yehuda David Bleich, a rabbi at Yeshiva University and professor at its law school, and Rabbi Shalom Dover Levin, the chief librarian of the Chabad Library in New York. Rabbi Bleich is not opposed to the agreement in principle and recognizes its importance in the Diaspora, but he believes that there are halakhic flaws in the Beth Din of America agreement. For a detailed summary of his method, an alternative proposal, and sources, see the article of his student, written under his supervision, Shalom C. Spira, $A$ Combination of Two Halakhically Kosher Prenuptial Agreements to Benefit the Jewish Wife, SCRIBD, tinyurl. $\mathrm{com} / \mathrm{zl}$ s86ko. By contrast, Rabbi Levin appears to reject the idea that it should be possible to make an agreement that allows divorce because of separation, in the absence of any other grounds, and he is against the halakhic concept of divorce. See Levin, supra note I 8; Levin, Teguva 5 [Comment no. 5], Din OnLINE (Apr. 28, 20I 5), tinyurl. $\mathrm{com} / \mathrm{ybn} 8 \mathrm{gx} 72$. His reaction, similarly to that of other Chabad rabbis, seems to come in response to initiatives of certain Hassidim and of American ultra-Orthodox in general to encourage the signing of such agreements. E.g., Libby Herz, Will the Halachic Prenup Catch On, Col Live (April 28, 20I 5), tinyurl.com/js6fyow; Allison Josephs, Breaking News: Halachic Prenup Backed by Major Haredi, Jew IN THE CITY (March I8, 2015), tinyurl.com/ zmhqfbw.

32 Sherman, supra note 28 , at 375 (emphasis in original). The article was written against the agreement of the Tzohar rabbis' organization.

33 The Prenup, supra note $\mathrm{I} 3$.

34 A letter of support by Rabbi Weiss appears on The Prenup, supra note I3. For an analysis, see Chaim Jachter, Rav Osher Weiss' Endorsement of the RCA/BDA Prenuptial Agreement, tinyurl.com/jxf $4 \mathrm{~d} 7 \mathrm{j}$. 
Goldberg. To the best of my knowledge, none of the first three expressed explicit support for the Israeli agreement, ${ }^{35}$ and the position of Rabbi Zalman Nehemiah Goldberg is unclear. ${ }^{36}$ Nevertheless, he made some explicit statements in which he stated that the agreement "is good for abroad" 37 or "for the U[nited] S[tates], where rabbinical courts have no authority." 38

The distinction between Israel and the Diaspora appears also in statements of other rabbinical judges, and it is largely explained by the difference between the legal status of rabbinical courts in the two communities. This is apparent in the words of Rabbi Dichovsky, offering at the end of $20 \mathrm{I} 2$ a more conservative prenuptial agreement than that of the Beth Din of America (he required a ruling by the rabbinical court for the imposition of spousal support in the amount of $\$ 2,000$ per month to apply during the separation), but determined that it was applicable to the Diaspora, where the rabbinical court has no government authority and the power of coercion. 39 And it is apparent in the words of Rabbi Yaakov Ariel, who opposed the agreements in Israel and distinguished between it and the United States: "In the U[nited] S[tates] there have been agreements for many years, but the judge Rabbi Uriel Lavi claims that the rabbinical court succeeds in expediting divorces more than any of the agreements." 40

Rabbi Lavi was also careful to note in his articles that his opposition to the agreement was not directed against America, although there is no doubt that the problems found in the Mutual Respect Agreement are also present in the American agreement. He argued that the legal reality is different (without explaining how it solves the halakhic problem of the coerced get). In one such article, he explained why the American agreement enjoys rabbinical endorsement, whereas the Israeli one does not. According to him, rabbinical support is given to the agreement in a situation in which there is civil divorce, which creates a legal situation that the absence of a get cannot change, but it is not relevant in a reality in which religious law alone controls the execution of the divorce. ${ }^{4 \mathrm{I}}$ In the most detailed article he wrote against the Mutual Respect Agreement, he did not mention the American agreement at all (although it is clear that his arguments against the Israeli agreement, and in particular the concern with coerced get according to the Rashba (Rabbi Shlomo ben Aderet, Spain, thirteenth century), are also valid against the American agreement), but he noted that that the agreement proposed by Rabbi Bezalel Zolti "is intended to residents

35 See David Mescheloff, Communications, 44 Tradition I03, IO4-O5 (20II). He claims that the approvals were indeed granted to America alone, because of the differences in the legal status of the Israeli rabbinical court, which does not require the consent of the parties to litigate the divorce.

36 The debate around the issue of his support for the Israeli agreement is one of the important points of contention between advocates and opponents of the agreement. The drafters of the Mutual Respect Agreement argue that they received his support and assistance in drafting the agreement. See the answer in the website of one of the organizations that stand behind the Israeli prenup: Kolech, http://tinyurl.com/lkan7vf (last visited May I4, 20г8). But his opponents reject this claim. Uriel Lavi, Od Al ha "Heskem leKavod Hadadi" [More about the "Mutual Respect Agreement"], 2I TzOHAR I 55, I 58 (2005). Tzohar officials also claim that their agreement is acceptable in the opinion of Rabbi Zalman Nehemiah Goldberg, but do not claim his explicit consent. Avraham Stav, Teguvah laTeguvot [Reply to Comments], SRUGIM (Jan. 7, 20I6), tinyurl.com/z5yw9xc. Rabbi Stav even suggested a reason why Rabbi Zalman Nehemiah Goldberg is wary of granting explicit support for the agreement.

37 Quoted in LeVMORE, MiN'i, supra note Io, at 72 n.I93.

38 Zalman Nehemiah Goldberg, miPiskey haGarzen Goldberg - Hilkhot Ketubot [The Rulings of Rabbi Goldberg: Halakhot of Ketubot], 5 Avnei Mishpat 26 (2006).

39 Shlomo Dichovsky, Akhifat Get [Enforcement of the Get], 25 Seridim I63, I73-74 (2013). See also Rabbi Lavi's statement about Rabbi Dichovsky's opposition to the Mutual Respect Agreement, Lavi, supra note 36, at I 58 .

40 Avinadav Vitkon, haRav Ariel Mistayeg me-Heskem Kedam haNissuin Shel Tsohar [Rabbi Ariel Disapproves of Tzohar's Agreement], ArUTZ SHEva (March 4, 20I5), tinyurl.com/ht6lxxk.

4I Lavi, supra note 36, at I 58 . 
of the Diaspora where the rabbinical court has no authority to force the husband to litigate the divorce before it. Therefore, the proposal is intended to make the husband need the rabbinical court." ${ }^{2}$ There is no doubt that this last statement is correct, and the editor of the journal saw to it to include Rabbi Zolti's proposal as an appendix to Rabbi Lavi's article, emphasizing repeatedly that the proposal is designed for the Diaspora only, where "the woman has no legal means of forcing the husband to appear before a competent rabbinical court to arrange the get," and "certainly there is nothing in Rabbi Zolti's proposal that touches on the legal situation in Israel, where the rabbinical court is authorized by law to litigate divorce cases, and recognized divorce between Jews is only by means of a get." ${ }^{3}$ Possibly, to emphasize that in Israel it makes no sense at all to speak about any agreement, the editor included a facsimile of the decision of the Chief Rabbinical Council, from 1986, that rejects any suggestion of an agreement that would allow a woman to obtain a get in any other way than by order of the rabbinical court, and ends by stating that proposals of this type represent an assault on the institution of marriage of the people of Israel.44

The most explicit statements appear to have been made by Rabbi Shlomo Amar, former Chief Rabbi of Israel. In two long responsa, he went to great length to establish the validity of the American agreement. $45 \mathrm{He}$ removed one after the other the objections raised against the agreement, even among Israeli rabbis. Still, it is necessary to consider the opening of the first responsum:

The cry of the daughters of Israel has reached us, and in particular of those in the Diaspora, where the authority of the rabbinical court is not recognized by the authorities to impose penalties and exclusions on get refusers, in order that they may fulfill the commandment of the sages who ruled that they should divorce, after they have already divorced in civil court. 46

And we should consider also the end of his responsum:

Therefore, it appears in my opinion that this agreement, which was established by the late Rabbi of Jerusalem, Rabbi Bezalel Zolti, is good and correct, and there is great utility in preventing aginut among the daughters of Israel abroad, and in preventing [the commission of] severe prohibited acts by married women, God forbid, and the increase in the number of mamzerim, ${ }^{[47]}$ may God preserve us. $4^{8}$

At this point, the reader may wonder, if there is no halakhic problem with the agreement, and the agreement is a proper tool for solving the problem of aginut, why should it be restricted only to the Diaspora?

The foregoing appears to suggest an answer to the conundrum. In the United States, the agreement is needed primarily to compel the husband to appear in rabbinical court, which he naturally does not have to do in the absence of a personal obligation to do so. The agreement also exerts

42 Uriel Lavi, Heskem Kedam Nissuin Lefiv haMesarev leHitgaresh Mehuyav beTashlum [Prenuptial Agreement under Which Payment Is Imposed on the Man Who Refuses to Divorce], I4 ShURAT Hadin 245, 283 (2008). Rabbi Zolti's proposal was written in 1983 and published. See Bezalel Zolti, be Inyan Takkanat Agunot [Regarding the Agunot Ordinance], 57:7 HaPARDES, sec. 30.

43 Lavi, supra note 42, at 289-94. Quotations from the long note by the editor are from pages $293-94$.

44 Id. at 295.

45 Shlomo Amar, Responsa Shema Shlomo 6:3 I I-28 (2008).

46 Id. at 3 II.

47 Mamzer is a person born from certain forbidden relationships. The common case is that of a person born from a married Jewish woman and a Jewish man who is not her husband. If the get is not valid, so the woman is still married to her husband, her child from another Jewish man will be a mamzer.

AMAR, supra note 45 , at 3 I9. 
financial pressure on recalcitrant husbands, because the American rabbinical court cannot impose its decision on the parties by virtue of law. By contrast, in Israel there is no need for an agreement because the rabbinical court has exclusive jurisdiction to litigate divorce cases, and the parties are already obligated to appear before it, whether they like it or not. The rabbinical court also has government power to enforce its orders to divorce, irrespective of any agreement between the parties.

That is a correct and necessary distinction, but it is not sufficient. First, we must distinguish between "unnecessary" and "inappropriate," and certainly "prohibited." If the agreement is halakhically acceptable, there should be no obstacle to implementing it in Israel as well. Second, the mere statement that the agreement is unnecessary in Israel is problematic. It is quite reasonable to assume that the existence of an agreement would greatly facilitate the divorce proceedings of couples who signed it, and prevent long litigation, which is its main goal in Israel. The argument brought by Rabbi Yaakov Ariel on behalf of Rabbi Lavi, that the tools available to the Israeli rabbinical court can arrange a divorce more quickly than can the agreement, is problematic to say the least. Rabbi Lavi certainly knows that some judges would almost never apply the restraining orders that Israeli law allows against those who refuse to abide by their order to grant the divorce, ${ }^{49}$ because they perceive these tools as halakhically problematic, even if a ruling exists ordering the divorce. $5^{\circ}$ At least part of the initiators of the agreements in Israel appear not to believe that the rabbinical courts provide an adequate solution to the problem of get refusal, and therefore decided to "assist" the courts, but Rabbis Lavi and his colleagues take a highly negative view of this assistance.

It is therefore entirely clear that the opposition to the Israeli agreement is not due to reasons of efficiency, but because of halakhic reasons. Thus, it is necessary to explain why some of the decisors do not reject the American agreement. I argue that there is opposition in principle to the Israeli agreement, which stems from halakhic and systemic reasons. It is possible to demonstrate that (a) some believe that in Israel it is possible, and therefore appropriate, to act more stringently than in the Diaspora with regard to the concern for the validity of the get; and (b) whereas the American agreement strengthens the rabbinical court, the Israeli agreement appears to weaken it. As far as the rabbinical judge in Israel is concerned, it is not merely his desire not to surrender power and authority, but his perception that divorce law has halakhic significance. The essence of this argument becomes manifest if we examine the role of the rabbinical court in implementing the agreement and its role in the decision concerning the grounds that require a divorce, as well as its ability to impose sanctions on the recalcitrant husband.

As I show below, these arguments are joined into one, according to which existing Israeli reality allows ruling lechatchilah, whereas American reality is one of bediavad, which allows using lenience in divorce law; such lenience is not desirable, and perhaps even impossible, in Israel.

49 Hok Batey Din Rabbaniyim (Kiyum Piskey Din Shel Gerushin) [The Rabinical Courts Law (Implementation of Divorce Judgments) Law] 5755-I995.

50 Rabbi Lavi himself was involved in the debate about the halakhic validity of the restraints imposed by the law. See Uriel Lavi, Beur Halakha Shel Harhakot deRabbenu Tam [Clarification of the Halakha for the Ban of Rabbenu Tam], 8 Shurat Hadin 436 (2003); but see Goldberg, Coerced Get, supra note 4, at 265-96. Statistical data, as of the previous decade, also indicate that on average only in about a quarter of the cases in which the rabbinical court ordered imposing and coercing the get, were also restraining orders issued, and in some rabbinical courts the rate is much lower. See Ruth Halperin-Kaddari \& Tamar Adelstein-Zekback, Proyect Pai, Duah Mispar i: Hok Batey Din Rabbaniyim (Kiyum Piskey Din Shel Gerushin) 5755-I995 [Pi Project: Supervision Enforcement and Implementation of Family Law in Israel], Report No.i: The Rabbinical Courts Law (Implementation of Divorce JudgmentS) 34-36 (2015). See infra note I45. 


\section{Lechatchilah and Bediavad: Israel and America}

The key halakhic argument against the validity of the agreement is that the increased spousal support payment that the husband undertook voluntarily is liable to create a coerced divorce. The articles written against the agreement reveal that the basis for this claim is the response of the Rashba (Rashba Responsa, Part 4, Section 40), and the way in which it is discussed by the Rema (Rabbi Moshe Isserles, Poland, sixteenth century) in his work about the SHULCHAN ARUCH (Even HaEzer, $\mathrm{I} 34,5$ ), a writing of decisive halakhic importance. ${ }^{5 \mathrm{I}}$ This is how Rabbi Dichovsky summarizes the matter in the first paragraph of his article that explains the problems with the Mutual Respect Agreement: ${ }^{22}$

The main section in these agreements deals with the obligation of the husband ... to pay a higher monthly spousal support to the woman (even if she is not entitled to it according to the law), if he refused to grant a get to his wife when she is suing him for it.

This section is problematic from the point of view of Jewish law, as the Rema cited the words of Beit-Yosef and the Maharik:[53] "If fines were imposed on him for refusing to divorce it is not called coercion, because he made the get contingent upon something else and can pay the fines and not divorce." But he added on behalf of the Rashba's responsum: "And some adopt a strict opinion even as follows, that it is good to act lechatchilah and to absolve him from the fine ...." This statement of the Rashba, which the Rema shows that it concerns lechatchilah, is at the heart of the difficulty of using financial sanctions for obtaining the get ... In view of what the Rashba and the Rema have said, it is clear that there should be no self-imposed monetary sanction on the part of the husband, forcing him to divorce his wife, for fear of coerced get. Therefore, such a clause in divorce agreements is not acceptable, and the courts will not perform the $g e t$ in such cases. ${ }^{54}$

The distinction between lechatchilah and bediavad and the influence of the Rashba and the Rema are emphasized also in the summary of the long article by Rabbi Lavi:55

According to the Rashba, if the husband changed his mind and no longer wants to grant the get, but because of the constraint of the fine he agrees to divorce, the get is invalid by Torah law. And according to the Maharik the get is valid. In practice, there is a majority who take the strict approach that agrees with the Rashba ... . Concerning the parties that signed the prenuptial agreement, called the "Mutual Respect Agreement," according to the teaching of the Rema a get should not be arranged, and they must cancel the agreement. But bediavad, if a get has been arranged and it is clear to the rabbinical court that the husband granted it voluntarily and unrelated to the fine, the get is valid. And some say that it is possible to arrange a get under these circumstances lechatchilah, and in a ruling of the Supreme Rabbinical Court $\left(\mathrm{vol} \mathrm{2,} \text {, } \mathrm{I}_{4}\right)^{[56]}$ it was decreed that in any case it is necessary to cancel the fine before arranging the get.

5 I For example, the Rashba's ruling and the discussion at hand, being mentioned dozens of times in the long article by Rabbi Lavi, Lavi, supra note 42; most of discussion revolves around these statements.

52 Shlomo Dichovsky, Heskemey Mamon Kedam Nissuin [Prenuptial Financial Agreements], 2I Techumin 279 (200I).

53 The Maharik (Rabbi Joseph Colon, Italy, fifteenth century) disagrees with Rashba and maintains that self-imposed obligation is not coercion, only an obligation imposed by others is. RESPONSA MAHARIK, sec. 63. Naturally, this opinion is of great importance for supporters of the agreement. By contrast, opponents of the agreement sought to downplay the value of the opinion or minimize its scope. E.g., Lavi, supra note 42, at 255-64; Schnieder, Rabbi Sternbuch, supra note 30. By contrast, see Aviner \& Stav, supra note I7, at 88.

54 Dichovsky, supra note 52, at 279-80.

55 Lavi, supra note 42.

56 Appeal 47/1956, supra note 30. 
If the get was arranged by exercising the agreement or by virtue of a threat to exercise it, according to the Rashba the get is void, and some say that bediavad the get is valid. ${ }^{57}$

My argument is that according to this opinion, the reality in Israel, where the rabbinical court has government authority, makes it possible to adopt a stricter attitude and rule in accordance with lechatchilah standards. This means that any attempt to institutionalize an agreement that can be valid only bediavad must be rejected. By contrast, the legal reality in the United States is completely different, and the rabbinical court lacks coercive power. This is a reality of bediavad, and therefore "this agreement [the American one] and the special circumstances involved in it should be discussed apart from the 'Mutual Respect Agreement,"” says Rabbi Lavi. ${ }^{8}$

As I noted in the opening of the article, the spirit of Jewish law in general and Israeli law in particular tends, for obvious reasons, to adopt a strict approach wherever there is fear of coerced get because of its dire implications. The same is true in the present case. Israeli rabbinical courts feel, and rightly so, that they can strive for better gittin than those granted abroad, partly because they do not have to confront the threat of civil divorce, and the couple can divorce only with the help of the rabbinical court. This allows it not to have to compromise and rely on lenient opinions, because the couples are locked within their marriage until the rabbinical court decides otherwise. By contrast, in the Diaspora, from the point of view of state law, the woman does not need a rabbinical court to get married; therefore we need to make it easier for her halakhically as well, and enact for her an agreement that would require the husband to appear in court and give her a divorce in the case of separation, so as "to prevent [the commission of] severe prohibited acts by married women, God forbid, and the increase in the number of mamzerim, may God preserve us," in the words of Rabbi Amar. 59 The reality in the Diaspora is one of overseas emergency (sheat hadehak), which requires compromising on the quality and validity of the get to prevent one of the most severe offenses in the Torah.

One of the Beth Din of America rabbis suggested interpreting the consent of Rabbi Asher Weiss similarly:

Rav Weiss notes that the Rema fundamentally rules in accordance with the Maharik and not the Rashba, since he concludes "it is good to lechatchilah accommodate the Rashba's opinion," meaning that it is preferable to satisfy the Rashba's opinion but fundamentally the Halacha follows the Maharik .... Although it is improper, as we noted, to create a prenuptial agreement entirely based on the Maharik, nonetheless since the Rema essentially follows the Maharik, there is a limit as to what extent we must be concerned for the opinion of the Rashba. Thus, since the 1992 document is entirely different than the Rashba's case,${ }^{60}$ one need not be concerned that it does not satisfy the Rashba's concern. ${ }^{6 r}$

Lest we think that the Rashba is entirely irrelevant to our discussion, but understand that we must show concern for him Lekhathilah, although within reasonable limits, the author adds immediately the following story about the rabbinical court in Jerusalem:

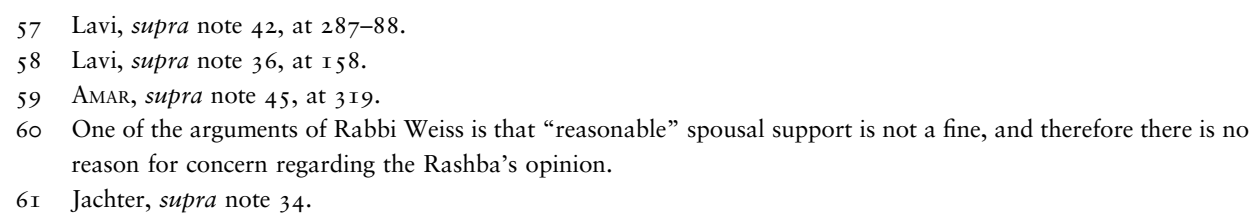


I witnessed a similar approach adopted by the Jerusalem Beit Din, consisting of Rav [Zalman Nehemiah] Goldberg, Rav Masood Elchadad and Rav Shlomo Fisher, in the situation described above where the husband signed an agreement providing for penalties in case he did not give his wife a Get. The agreement was made in Israeli civil court and Israeli civil law did not allow the Beit Din to nullify the agreement. Rav Goldberg proposed solving the problem by neutralizing the penalty by the wife signing an agreement that she would return any money the husband would pay as a result of the penalty .... When Rav Elchadad expresses reservations about this approach, Rav Fisher responded that there is a limit as to the extent one must be concerned for the Rashba's strict ruling, since the Chazon Ish endorses the Rema's ruling that fundamentally the Halacha follows the Maharik. ${ }^{62}$

If the evidence is accurate, it tells us that with regard to the agreement that is similar to the agreements which we are discussing (although in this case, according to Rabbi Zalman Nehemiah Goldberg's proposal, the husband sustains no harm, therefore this appears to be an even easier case than that of the agreements discussed above), the preferred option of all three rabbinical judges was to act lechatchilah, that is, to cancel the agreement. But when it became clear that they could not do so, one of the judges still expressed fear that the get might not be valid according to the Rashba, who argues that it is necessary to act lechatchilah, and therefore there is a problem; by contrast, his colleague pointed out that the Rashba is not the alpha and the omega, and that there are also situations of bediavad, in which it is possible to rely on the Maharik.

The one who presented the proposed distinction in its sharpest form is Rabbi Shalom Mashash, who served as Chief Rabbi of Morocco, and later as Chief Rabbi of Jerusalem. In a responsum that he wrote in I98 $\mathrm{I}$, he explained the halakhic justification of the prenuptial agreement that was in use in Morocco, in which the husband undertook to pay the sum of 5,000 francs per day, in case the couple were divorced in civil court but he still did not grant a get. He explained the positions of the Rashba and the Rema, as well as the lenient positions, and summarized the matter as follows:

Your eyes will see that the main part of the Halakha is lenient, and also bediavad if they are already divorced, we are lenient, and only where it is possible and everything is ready before us, without pain and trouble, it is necessary to insist on all the strictness .... And simply, in my opinion, this is what the Chief Rabbi [who created the agreement in Morocco] based himself on, to ease up instead of causing igun, where he divorces her in civil court and goes free to marry another woman, and will travel to any place he likes, and leave her chained (agunah) all her life still a wife, which leads to several pitfalls .... And in this way, the stringency already becomes lenience, because by means of the stringency that we rule in accordance of the stringent opinion, we anchor the woman and assist the criminals who transgress against the prohibition [of having sexual intercourse with a] married woman. ${ }^{63}$

He repeated these opinions later in answers sent to New York in 1984, which were designed to justify the agreement used in Morocco, as justifications for the agreement that began to take shape then in the United States. ${ }^{64} \mathrm{He}$ did not deny the fact that the agreement is inconsistent with the Rashba's position ("all enactments in the world will not help and prevent in his opinion a coerced get" ${ }^{65}$ ), but the reality in the Diaspora unfortunately does not allow us to rule based on the lechatchilab method that he represents:

62 Jachter, supra note 34 .

63 Shalom Mashash, Responsa Tvuout Shamash, Even HaEzer I 27-28 (I98I). See Levmore, Rabbinic Responses, supra note IO, at 3I-34, for a discussion of the agreement created in Morocco in I953, which was backed by then Chief Rabbi Shaul Even Danan, about the responsa of Rabbi Mashash and their background.

64 Shalom Mashash, Responsa Shamash Umagen, Even HaEzer i:233-39 (I985).

65 Id. at 237. 
And if we now try to satisfy the demands of all the decisors in this matter ... and if we think about this matter in terms of lechatchilah, we will certainly not be able to sort out the matter.... Therefore I said, that even if a portion of stringency or doubt remains, because of the strict opinion of the Rashba, nevertheless in the matter at hand where there is fear of igun, and certainly of mamzerut, it is appropriate to rule in the matter based on the main law, without strictness, and to think bediavad, and given that in the opinions of Rabbi Karo and of the Rema it is not appropriate to act in this way, they ruled to show lenience, as did most of the lenient decisors mentioned above ... . Therefore, even though it is appropriate to observe all the strictness, even if it is to contradict Rabbi Karo in matters of severe unchastity, in any case in a matter of this type, the strictness leads to lenience lest we end up producing mamzerim, and create igun, which is why it is appropriate to leave the law intact and not to adopt stringency. ${ }^{66}$

In sum, the position expressed in the last paragraphs argues that it is necessary to distinguish between Israel and the Diaspora. In Israel, where divorce is conducted exclusively in rabbinical courts, there is room to adopt a strict stance and show concern for the Rashba's opinion and that of the abronim who followed in his footsteps, and therefore oppose the agreement. By contrast, in the Diaspora we have no choice but to withdraw to a more lenient position, because of various circumstances, and decide that we are not concerned with the opinion of the Rashba and his followers.

It is clear that whoever prohibits the use of the American agreement thinks otherwise. In his view, the reality abroad should not affect the required strictness on the sensitive issue of the get. ${ }^{67}$ In this matter we must always rule according to the strict opinions, and those who validate agreements, they themselves "assist in transgressing against the prohibition [of having sexual intercourse] with a married woman and increase the numbers of Jewish mamzerim." 68

At the other end of the spectrum, the position in favor of the Israeli agreement, or at least the position that recognizes that the current situation is not satisfactory despite the authority of the rabbinical court, tends to argue that the circumstances in Israel are not significantly different from those in the Diaspora, and that even in Israel it is not always possible to rule based on the strict lechatchilah approach. In this opinion, the state authority of the rabbinical court, and the inability to obtain a divorce without it, still do not make Israel into a reality where lechatchilah holds sway, that is, where a strict approach can be adopted. The absence of civil divorce in Israel does not prevent a married couple from starting new relationships, even without a divorce. Under certain circumstances, the institution of "cohabitation," which is highly developed in Israel, even grants officially recognized status to such relationships. ${ }^{69}$ But even without an institutionally recognized

66 Id. at 234 .

67 The fundamental position of Rabbi Elyashiv was that a problematic reality is not a consideration to be taken into account in order to adopt a lenient ruling in general, and in particular in divorce law. See Reiner, supra note 8 , at 267-68, 270-76.

68 Schnieder, supra note 30 (quoting Rabbi Sternbuch). It may be possible to assume that those adopting a strict position are already part of the ultra-Orthodox community and that the chance of their remarrying without a get is null. The broader Jewish community is of less interest to them, and in any case it is better from their point of view that the halakha and its exponents should not recognize an agreement that in their opinion is most problematic, even if there is occasional concern that an aguna will marry without a get, on her own authority. A similar debate appears to have taken place concerning the validity of a get granted after a woman appealed to the civil court in France in a suit against her husband. Orthodox rabbis in Israel voided it, whereas French rabbis not only did not void the get, but encouraged women to do the same. See Amihai Radzyner, Lo haMidrash 'Ikar Ela haMa'aseh: Al Sidur Gittin leAhar Teviot Nezikin veAl Medinyut haPirsum Shel haPesikah haRabanit ["The Essential Thing Is Not Studying, but Deed:" Get Procedures after Tort Claims and the Publishing Policy of Rabbinical Court Rulings], 45 Mishpatim 5, 68-72 (2015).

Shahar Lifshitz, External Rights of Cohabiting Couples in Israel, 37 Israel Law Review 346 (2003-04). 
relationship, it is clear to all that Israeli society is not so fundamentally different from that of the American Jewish community, and halakhic issues involving severe prohibitions of relationships with married women, including the birth of children resulting from such relationships, are not rare. Rabbi Eliyahu Bakshi Doron presents these realities as factors that attest to the need for an Israeli agreement, even if not exactly the agreement being discussed here. $7^{\circ}$

Clearly, the initiators of the Israeli agreements believe that contemporary Israeli reality requires such an agreement, and that it is the best one available. According to them, the agreement motivates couples who are considering marrying not according to halakha or living together without marriage, to marry in a halakhic ceremony..$^{7 \mathrm{I}}$ They also appear to understand that the dispute between them and their opponents hinges primarily on whether the reality in Israel mandates renouncing the "glatt" position, as Rabbi Dichovsky calls it, and whether changes in the social reality of the people of Israel are a consideration at all in determining the halakha in this matter. This is what Rabbi Avraham Stav has to say:

It is also important to understand the whole reality we face .... It is easy to close your eyes before this reality based on claims of preserving the tradition of our ancestors, but anyone whose eyes are open and his heart is not sealed will do all that is in his power to fortify the sanctity of the institution of marriage among the general public, with the tools that the Halakha gives us. $7^{2}$

This is what Rabbi Ben Zazon, who helped draft the Mutual Respect Agreement, says:

The halakhic picture indicates that this agreement is valid lechatchilah, or at least bediavad, and it seems that these are times of emergency, and it is appropriate to opt for this way lechatchilah.73

\section{Involvement of the Rabbinical Court and the Grounds for Divorce: Israel and the United States}

Comparing the payment clauses of the American and Israeli agreements illustrates some of the differences in the details and in one basic principle: the very fact that the separation between the spouses, whatever its cause, obligates the husband (in the Israeli agreement this can also be the wife) to pay a significant amount of spousal support, an amount designed to exert economic pressure that would result in the granting of the get. My argument, following from the previous one, is that another reason for the distinction between the United States and Israel is American reality, in which a halakhic divorce is not required by law. In this situation, there is a need for an agreement that would obligate the husband to appear before the rabbinical court (which the Israeli agreement naturally does not require). Such agreement must adopt a lenient divorce policy, similar to the one used in the civil courts, nor does it require the grounds, stipulated by the halakha, for coercing a

70 Eliyahu Bakshi-Doron, Hatsa'a lePitron Be'ayat Sarvaney haGet [A Proposal for Solving the Problem of Get Refusal], 35 Techumin 264 (2015).

7I Stav \& Stav, supra note I7, at I I6. From the tone of the writing we glean that in an ideal world it would be desirable to renounce the agreement. Aviner \& Stav, supra note I7, at 7I, explain the problems associated with divorce proceedings in Israel and the fact that the agreement may prevent couples, who are deterred by these problems, from marrying not according to halakha.

72 Stav, supra note 36.

73 David Ben Zazon, ha "Heskem leKavod Hadadi": haMetsadedim vehaMitnagdim [The "Mutual Respect Agreement": Supporters and Opponents], 25 TzoHar I, 4 (2006). 
divorce, in order to force recalcitrant husbands to pay the amount specified in the agreement. By contrast, in Israel the rabbinical court is already the only judicial institution that can debate whether the spouses are to be divorced, therefore there is no reason to adopt new or more lenient grounds for divorce, which are perceived by many rabbinical judges as being influenced by legal systems foreign to the halakha.

It is clear that the main motivation for creating the agreements in the Diaspora stems from the existence of a civil system in which Jews can obtain a divorce. The fear of transgressing halakhic prohibitions that may be caused by the absence of a get and the lack of authority of the rabbinical court to impose compliance on the parties has led to the creation of the agreement. Therefore, advocates of the agreement must admit, however reluctantly, that civil divorce (or the grounds that allow it) 74 are sufficient grounds for forcing the divorce, and thus for activating the agreement. As we have seen, 75 the agreement created in the 1950 in Morocco has been designed to solve the problem that arises whenever there is concern that the parties will settle for civil divorce alone. The Moroccan rabbis already stated that civil divorce is a binding ground for halakhic divorce. ${ }^{6}$ This is also the approach of the Beth Din of America, as presented by Rachel Levmore, who does not try to conceal its innovativeness:

It is given that the Beth Din of America rules in accordance with the halakha. Concurrently, within the Talmudic and the rabbinic literature there is ample discussion of what are acceptable grounds for divorce. Whatever the case may be, it is clear that Rabbinical Courts will rule that a husband "must give his wife a get" only when some "fault" is proven to exist. Nonetheless, in the United States when a civil divorce is in place or in process, the Beth Din of America will rule that the husband should give a get. This ruling is itself based on "grounds" for divorce. Only following that determination by the Beth Din, can the process specified by their agreement proceed. 77

American rabbis write clearly about the policy of American rabbinical courts, which accept in practice the idea of the "defunct marriage" as ground for divorce. Rabbi Jonathan Reiss writes:

Additionally, one of the functions of a beit din proceeding is to bring peace and harmony into the world. In the context of a divorce case, this function includes taking measures to ensure that a get is given when a marriage is over .... An agunah, broadly defined, is a woman who is no longer in a functional marriage and who can not remarry because her husband can not or will not give her a get and is also not known to be dead. As a general rule, a marriage is no longer functional and a get should therefore be given in any case where a husband and wife no longer desire to live together as husband and wife or if a beit din concludes that there is no chance for shalom bayit [reconciliation] between them ... even if one party acts wrongly to the other, it is never correct for either the husband to withhold a get or for the wife to refuse a get when a marriage is clearly over. $7^{8}$

74 After all, the intention of Beth Din of America is to arrange the get before civil divorce takes place. See LeVMoRE, Min'i, supra note io, at 76; Michael J. Broyde Marriage, Divorce, and the Abandoned Wife in Jewish Law: A Conceptual Understanding of the Agunah Problems in America i 59 n.36 (2001).

75 Supra note 63.

76 Levmore, Rabbinic Responses, supra note Io, at $3 \mathrm{I}-32$.

77 Levmore, Preventing, supra note Iо.

78 Jonathan Reiss, Jewish Divorce and the Role of Beit Din, Jewish Law, http://tinyurl.com/y8057xqt (last visited May I4, 2018) (emphasis added, except the final emphasis). Rabbi Reiss relied on American Rabbis Henkin and Feinstein. This reliance is not entirely simple, because Rabbi Henkin spoke about a separation of one year, and Rabbi Feinstein mentioned a separation of a year and a half, in a situation in which the rabbinical court attempted to arrange a reconciliation and failed. Although the agreement is activated also without these 
Rabbi Michael Broyde, who served for many years as a Beth Din of America judge, writes similarly:

Based on these and many other sources, a proper halakhic posture should be that once the marriage is functionally over, and neither party wishes to remain married to the other, the role of a bet din (and everyone else) should be to settle the financial disputes between the parties, and to facilitate and encourage the writing of a Get.... It is in this spirit that the many prenuptial agreements (which do not require a finding of fault to require that a Get be given) have been suggested, and have received approbation or been formulated by such eminent contemporary poskim. 79

It would be correct to present the effect of civil law as tantamount to creating a state of bediavad, which requires lenience with respect to the grounds for divorce to avoid mamzerut, etc., whereas in Israel, where there is no fear of civil divorce, it is possible to act according to strict Jewish law, and there is no reason to show lenience. We have seen that this is how the matter has been presented by rabbinical judges in Israel, for example, Rabbi Zalman Nehemiah Goldberg, who explicitly stated that considerations of fault should be part of the agreement, but that in the United States these must be renounced because there is no alternative. ${ }^{80}$ The American decisor, Rabbi David Bleich, also presented the matter in this way in his proposed agreement, explaining that there would be differences between the United States and Israel. ${ }^{8}$ According to him, if there is an agreement in Israel, it would have to determine that a woman who leaves her husband voluntarily will not receive the spousal support specified in the agreement because this is what the halakha states, and in Israel it is not possible to marry not according to halakha. By contrast, "in the Diaspora, where often the husband takes a second wife without the permission of a hundred rabbis, and the woman marries against the prohibition, according to civil law, and her children are mamzerim, it makes sense to sign a contract obligating the husband in an absolute way, especially because in Western countries every woman can remove herself from her husband by a civil divorce." 82

This policy, which may be rooted in the bediavad conception of the Diaspora, is consistent today with the lechatchilah conception of many Jews, in other words, with the social (and in America, also the legal) convention that underlies their lives, and according to which the separation in itself is sufficient reason for divorce. Therefore, it is inappropriate to refuse the woman's demand for a get, irrespective of the question of the husband's fault, and without the need for the discretion of the rabbinical court. ${ }^{8}$

There are many among the advocates of the Israeli agreement who also espouse a similar concept of divorce without fault, upon the demand of one party, even if it does not originate in civil court

restrictions, these sources are presented as a basis for its activation because they accept the "defunct marriage" claim as a ground for divorce.

79 Michael J. Broyde, Response, the 1992 New York Get Law: An Exchange, 3I Tradition 27, 29 (I997).

80 Goldberg, supra note 38 , at 26.

8 I J. David Bleich, Hatsa'a lePitron Be'ayat Ba'al haMesarev leHitgaresh [Proposal for Solving the Problem of a Husband Who Refuses to Divorce], 38 Or Нamizrach, 57, 65-66 (1990). See also supra note 3 I.

82 For the opinion of another Beth Din of America rabbinical judge, in a lesson about the agreement, see Rabbi Michoel Zylberman, Contemporary Topics in Even HaEzer 8: Prenuptial Agreements, YUTorah Online (Aug. I3, 20I5), tinyurl.com/z98wob7. Starting at minute 22, Rabbi Zylberman mentions Rabbi Lavi and his opposition to the idea of divorce on demand, as in practice it exists in the agreement (discussed below), but notes that even if in principle Rabbi Lavi is right, we have no alternative because we live in a society in which people separate without a get, and we have no ability to keep them married. Naturally, this presumes that the reality in the Diaspora is one that requires lenience, unlike the situation in Israel. BROYDE, supra note 74 , at 36-4I; see also id. at 68-70, 8I-83. 
but in social concepts influenced by Western ideas of divorce (which opponents of the agreement hold against it, as we shall see). ${ }^{8}$ For obvious reasons, the rabbis who support the Israeli agreements do not generally present the social reality as welcome, but as a reality bediavad, in which the agreement is required in order to minimize halakhic and family damages, including acts of faithlessness during the separation, and the birth of mamzerim. ${ }^{85}$

By contrast, opponents of the agreement see it as a serious threat to the basic concept of halakhic divorce laws, according to which in the absence of agreement between the parties to a divorce, only the rabbinical court can obligate them to do so, not a contract signed by them in the distant past; therefore they reject this document. Some of them believe that because of the difficult circumstances in the Diaspora, it makes sense to consider there (and only there), such an agreement, and some oppose it even in the United States, as we have seen. In this second group are, for example, Rabbi Sternbuch, who argued that the agreement allowing the wife to force her husband to divorce her unlawfully "may undermine Jewish matrimony," 86 and Rabbi Levin, who decreed that activating the agreement in the absence of halakhic grounds to coerce it results in a void get. ${ }^{87}$

Regarding the State of Israel, most opponents of the agreement seem to have raised this argument, some at length, others briefly, and we need not list them all. Beyond the debate taking place among the rabbinical judges in Israel whether separation is in itself a halakhic reason for coercing a get $^{88}$ it is clear that one of the strongest objections of rabbinical judges in Israel to the agreement is that it makes the court superfluous in elucidating the grounds for divorce and in decreeing whether the spouses are to be divorced, and makes it superfluous as the only body that can arrange the get, denying it discretion in the matter of whether it is appropriate to arrange a get at all. The agreement damages the current status of the Israeli rabbinical courts and reduces the scope of their jurisdiction. In practice, the agreement replaces the rabbinical judge by determining the circumstances under which the get is to be arranged.

For this reason, a rabbinical judge may oppose the Israeli agreement and support the American one. From his point of view, in Israel the status and scope of jurisdiction of the rabbinical courts will change for the worse, whereas in the United States, the land of bediavad, the opposite will happen: the agreement will strengthen the power of the rabbinical court and grant it authority that it does not have without the agreement. Another way of looking at it is as follows: the American legal situation could require us, for lack of a better alternative, to conclude an agreement that in practice enshrines the norms that have already been generally accepted. Otherwise Jewish couples will divorce without a get, with all that this entails. By contrast, in Israel the grounds for divorce remain

84 Ram Rivlin, Religious Norms between Ethics and Law: The Death and the Afterlife of Jewish Divorce Law, 4 Oxford Journal of LAW AND Religion, 469, 476-77 (2015) ("These agreements reflect a clear endorsement of internalizing Western norms into Jewish divorce law.”). See also Avishalom Westreich, haZekhut leGerushin: Gerushin lelo Asham baMasoret haYehudit [No-Fault Divorce in the Jewish Tradition], 9I-93 (20I4).

85 Ben Zazon, supra note 73, at 6-7; Stav \& Stav, supra note I7, at II I-I 4 .

86 Schnieder, Rabbi Sternbuch, supra note 30.

87 Levin, supra note $3 \mathrm{I}$.

88 On the debate and its halakhic sources, see Avishalom Westreich, The Right to Divorce in Jewish Law: Between Politics and Ideology, i International Journal of the Jurisprudence of the Family i77, i89-94 (2010); Westreich, supra note 84 , at 86-9I; Rivlin, supra note 84 . Note, however, that even the rabbinical judges who favor long separation as a ground for divorce, for example, Rabbi Uriel Lavi, oppose the agreements. It is clear that they believe that even in the case of separation, factual clarification by the rabbinical court and its explicit ruling are still required to impose a get. The halakhic sources that address separation as a ground require a much longer separation than what is required by the agreements, and a situation in which it is clear that both sides prefer not to live together, contrary to the agreements, which address also situations in which the initiative to separate is that of one spouse, whereas the other is interested in reconciliation. 
in place in the legal world, and there is no possibility of divorcing without a rabbinical ruling that weighs them and decides whether they lead to imposing a get. This is the lechatchilab reality, because this is how the courts have acted across generations, and the practice must be preserved. ${ }^{89}$ What is acceptable in the United States, or at least not objectionable, in Israel appears to be contrary to the basic concept of the Jewish family because it virtually eliminates an institution of enormous scope known as the "grounds for divorce," and together with it the need for the rabbinical court to clarify them, so that there is no way of accepting it.

The decision of the Chief Rabbinate, from 1986, reflects this opinion:9 ${ }^{9}$

In these proposals there are sections that prove that the proponents have absolutely no knowledge of Halakha, or believe that they can force the husband to grant his wife a get by bypassing Jewish law .... They harm ... the institution of marriage, which is sacred to the people of Israel, undermine family life, and damage the women's rights and status. ${ }^{1}$

In his article against the Mutual Respect Agreement, which assumes that in Israel it is possible to preserve the halakhic concept in its purity, Rabbi Lavi writes:

The concept that stands behind the agreement is to allow divorce to each spouse even without an acceptable ground .... This concept is alien to the world of Torah, and derived from other domains .... A framework within which for no good reason, either spouse can dissolve the marriage, even after decades, and without any need to explain or to have a substantive discussion..$^{2}$

He does the same in the conclusion of his article, in which he contrasts the accepted halakhic concept with the different one represented by the agreement, a contrast between what is valid and what needs to be rejected:

A prenuptial agreement in which one spouse obligates oneself to pay money levied if refusing to divorce is not desirable because the agreement changes principles accepted since time immemorial in the Jewish institution of marriage. This change allows each spouse to dissolve the marriage, contrary to the consent of the other spouse, without justification and without grounds for divorce according to Jewish law, at times because of wanting an alternative spouse.

89 As mentioned above, the advocates of the agreement in Israel do not see a substantial social (and possibly even legal) difference between Israel and the United States, and therefore do not think that there should be a difference with respect to the agreement. Beyond that, it is clear that some of them understand how sensitive the rabbinical court is to a reduction of its authority, but they do not think that this argument is relevant. See, e.g., Stav \& Stav, supra note I7, at III.

90 Lavi, Prenuptial Agreement, supra note 42. Although the resolution speaks about a different agreement than the one we are dealing with, it is cited by its opponents. See, e.g., supra note 44 and accompanying text; Rabbi Shlomo Aviner, Mo'etset haRabbanut haRashit Al Heskem Kedam Nissuin: Hatsa'ot Hevel [The Chief Rabbinate Council on a Prenuptial Agreement: "Valueless Proposals"], SRUGim (May Iо, 2015), tinyurl.com/h5hgsyp. It is clear, therefore, that any agreement proposed in Israel must be opposed, and even if social reality has changed in the last thirty years, this is not relevant.

9I The last words should be understood in light of the fact that in Israel the agreements are reciprocal, and therefore a situation may arise in which a man will force his wife to divorce because he found another woman, and so on. Some of the opponents of the agreement deliberately cite this option, which indeed can happen, although the agreements are usually portrayed as being especially important for women who are liable to be refused the get. See, e.g., Avraham Zvi Scheinfeld, Heskem Mamon Kedam Nissuin [Prenuptial Financial Agreement], 22 TeChumin I48, I 54 (2002). 
This is not the case if the financial obligation is carried out subject to a ruling issued by the rabbinical court, to obligate the other party to divorce, provided that the exercise of the financial obligation has also been ruled by the rabbinical court. 93

The veteran rabbinical judge Rabbi Avraham Sherman presents the argument against the Tzohar agreement most broadly. ${ }^{94} \mathrm{He}$ repeats this argument many times and in many ways, and he stresses how alien it is to the spirit of the halakha. This appears to be the main argument in his article: for example, "the drafters of the prenuptial agreement 'excluded' the rabbinical court and the Torah of which it is in charge." 95

\section{Interim Conclusion}

From the above we can conclude that the American reality, where the rabbinical court has no state powers, can possibly justify bediavad the acceptance of the concept of civil divorce practiced there. But rabbinical judges argue that in Israel the legal status of the rabbinical court carries halakhic and moral weight. It is not appropriate to reduce its jurisdiction, vested in it by law, to litigate divorce claims and to decide whether to accept or reject them. It is not right to coerce a get when a rabbinical judge thinks otherwise, and thereby raise the specter of a forced get. And it is not right to accept an agreement that dramatically changes the way in which Jewish law has operated throughout the ages, and with it create the ability to break up the family. These three aspects are intertwined. This fundamental distinction arises from the different legal reality that Israel and the United States, but it does not remain merely theoretical. Rabbinical judges in Israel regard the agreement as a halakhic and moral threat, and as a document that damages the status of the rabbinical court, and therefore their attitude towards it is negative.

In the draft of a ruling, ${ }^{6}$ the head of the Tel-Aviv Rabbinical Court, Rabbi Chaim Shlomo Shaanan, heard the case of a woman seeking to activate a prenuptial agreement made in Israel in 1997. The language of the agreement is identical to the Hebrew text of the American agreement. 97 Over five pages, Rabbi Shaanan presents a series of reasons intended to show that the husband's obligation is invalid, both under the halakha and under Israeli law, and concludes by saying that even if it were valid, it is necessary to adopt a strict position and rule that a penalty that a person undertakes to pay creates a coerced get. His fundamental position is presented at the beginning of his remarks:

There is no doubt that this agreement and so forth ... comes to destroy the sacred institution of the family of the people of Israel .... The minute the woman decides to leave her husband ... she will be able to do that and win a lot of property .... Although the Torah desires that the man should divorce his wife and not the other way around, from now on the woman will divorce her husband against his will, whenever she likes, and not the other way around. Therefore, there is no doubt that such agreements should be rejected in

93 Lavi, Prenuptial Agreement, supra note 42, at 287.

94 Sherman, supra note 28.

95 Id. at 379.

96 Haim Shelomo Shaanan, Teshuvat haGaon Rabbi Haim Shelomo Shaanan [Responsum of Rabbi Haim Shelomo Shaanan], in Pinchas Shapira, Kedushat haNissuin: Odot Heskemey Trom Nissuin [On The Sanctity of Marriage: About Prenuptial Agreements] i6-20 (20I7). Eventually the spouses were divorced by agreement and there was no need to issue the verdict.

97 For a Hebrew rabbinic version of the husband's commitment in the American agreement, see AumAN \& HeRRING, supra note Io, at 54 . 
disgust. The argument that these agreements prevent igun is not true. In addition, not only do these agreements not prevent igun, but even create igun because if the husband grants a get at all because of such an agreement, there is great doubt whether the get will be valid, which will affect also the children who will be born..$^{98}$

There is no doubt that the same can be said in the United States as well; nevertheless, the agreement is accepted there and it works, whereas in Israel it is not. I explained above why this is so, and if the legal situation in Israel were different, it is reasonable to assume that the halakhic attitude toward the agreement would also change, at least in part.

\section{IS THERE A CHANCE FOR AN ISRAELI AGREEMENT?}

Is there any hope for the advocates of the Israeli agreement? Is there a chance that the rabbinical court will change its mind? Maybe, as I discuss in the following paragraphs. Note, however, that past examples are no guarantee that the same will happen also with regard to the issue at hand. There are certainly many differences between them and the agreement. Nevertheless, there is great value in examining these, which show that in several instances having to do with the issue of coerced get, rabbinical judges in Israel and abroad have changed their position. The changes occurred as a result of the fact that ever larger portions of the Jewish community acted, for various reasons, contrary to the declared lechatchilah position of the rabbinical court. Having no alternative, rabbinical judges were forced to act in accordance with the new reality. If more and more couples sign the prenuptial agreements, rabbinical courts in Israel may change their position.

It is possible to bring several examples of cases in which the rabbinical courts changed their position to a more lenient one and abandoned the stringent lechatchilah stance that was prevalent in the past. I describe only two such cases, which illuminate the two sides presented here: the fear of coerced get, created by the obligation to pay a high spousal support not subject to the discretion of the rabbinical court, and the change in the perception of the accepted grounds for divorce. ${ }^{99}$

\section{Women's Spousal Support in Civil Court}

According to Israeli law, a woman's claim for spousal support against her husband can be heard

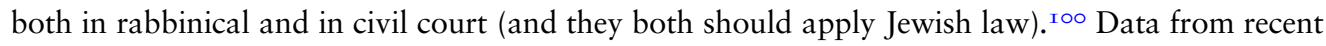
years show that the vast majority of spousal support claims are litigated in civil court, and the gap between the number of cases filed in civil and rabbinical courts increases year after year. ${ }^{\text {Ior }}$ Therefore, it would be odd to argue that a claim for spousal support filed by a woman in family court could have a negative effect on the validity of her get. Nevertheless, rabbinic rulings show

98 Shaanan, supra note 96 , at 20.

99 Another case in which we can see a change in position of the rabbinical courts in Israel, from a policy of lechatchilah to one of bediavad, an undeclared change but one that can be demonstrated in many cases, has to do with the issue of tort claims in civil courts by women who have been refused a get, against their husbands. The declared policy of the rabbinical courts is that this creates a coerced get, and therefore such a get cannot be arranged, but in practice it turns out that reality is different in the vast majority of cases. For further details, see Radzyner, The Essential Thing Is Not Studying, but Deed, supra note 68.

ioo Talya Einhorn, Private International LaW in Israel i 88 (2009).

ior Ruth Halperin-Kaddari, Keren Horowitz \& Lilach Sharvit, Nashim uMishraha beIsrael: Du-Shenaton Statisti [Women and Family in Israel: Statistical Bi-annual Report] 93-95 (2014). 
that there have been many judges who considered that a spousal support ruling in civil court is cause for concern that the get may be coerced. This position, which was quite common in the past, almost disappeared in recent years, or has become entirely marginal.

Before discussing the various sources, it is important to note that as far as the rabbinical court is concerned, the problem arises, among others, because statistics show that the amount of spousal support women are awarded in civil court is higher than what the rabbinical courts award, and it is also tied to the consumer price index, contrary to the prevailing position in rabbinical court. ${ }^{102}$ Another relevant issue is that the civil courts award spousal support even in cases in which the rabbinical court is likely to hold that no spousal support should be awarded at all, ${ }^{103}$ or that it should not be imposed because of insufficient evidence in the court's opinion, ${ }^{\mathrm{I}}{ }^{4}$ or that the obligation to pay spousal support can be terminated earlier than according to the civil court. $^{105}$ It is easy to understand that there might be a halakhic problem in imposing payments on the husband that according to halakha he is not obligated to pay at all, or in amounts exceeding the amounts that he would pay according to halakha. If this affects his considerations in granting the get, there can be an issue of coerced get.

We are not surprised to find that in the past this problem has concerned rabbinical judges. At a conference of rabbinical judges held in I979, several participants explained the problems caused by women filing spousal support claims in civil court, from defrauding the husband to instances of coerced get. ${ }^{\mathrm{I} 06}$ Rabbi Simcha Kook, the rabbi of Rehovot and the head of the rabbinical court there, stated categorically: "Spousal support awarded by the civil court is a coercion of the husband, a question of coerced get, and [in the case of] a coerced get the woman is a married woman really, this is a serious question to be discussed." ${ }^{107}$

Rabbi Mordechai Uriah, from the Haifa Rabbinical Court, explained that women file spousal support claims in civil court deliberately when they know that there is "no sufficient substance by [Torah] law to demand a get from their husband." The civil courts "award her spousal support in excess of what he earns, so it is self-evident that he was willing to give her a get." This is the problem of coerced get, and he recommends that rabbinical courts do not arrange gittin unless the woman renounces the spousal support awarded in civil court, otherwise "we are facing the real sin of a coerced get and the children are, God forbid, mamzerim." Iо8

I02 Id. at 96-98. The difference in the amounts of spousal support is not new. See Ariel Rosen-Zvi, Hilkhat haKerikhah uMerots haSamkhuyot veHashspa'atam Al haMishpaha veDinei haMishpaha [The Jurisdictional Race in Matters Connected with Divorce Suits and Its Impact on Family Law], I4 TeL-Aviv University LaW Review 67, 69 (1989); Eliav Shochetman, Ma'amad haIsha beDinei Nissuin veGerushin [Women's Status in Marriage and Divorce Laws], in Ma'amad haIsha baHevara uvaMishpat [Women's Status in Law and SocIETY] 380, 405-06 (Frances Raday, Carmel Shalev \& Michal Liban-Kobi eds., I995).

io3 For various examples, see Ariel Rosen-Zvi, Dine Ha-Mishpahah Be-Yiśra’el: Ben Kodesh Le-Hol 420-2I (I990); Ruth Halperin-Kaddari, Dinei Mishpaha Ezrahiyim Nusah Israel: Likrat Hashlama [Toward Concluding Civil Family Law: Israel Style], I7 Mehrarei Mishpat I05, II3-23 (200I); Ruth Halperin-Kaddari, Shikuley Musar be-Dinei Mishpaha veKeriah Feministit shel Pesikat haMishpaha beIsrael [Moral Considerations in Family Law and a Feminist Reading of Family Cases in Israel], in Iyunim BeMishPaT Migdar uFeminizem [Readings in Feminism, Gender and Law] 65 i, 654-67 (Daphna Barak-Erez et al. eds. 2007).

I04 Rosen-Zvi, supra note I02, at 70; Shochetman, supra note I02, at 4-6.

I05 E.g., FA (Hi) I 26/02 Shlomo Rosenblum v. Shoshana Rosenblum (Sept. I, 2002), Nevo Legal Database (by subscription) (Israel); FA (TA) I050/04 A.A. v. A.A. (Mar. Io, 2005), Nevo Legal Database (by subscription) (Israel).

io6 Kenes haDayanim, 5739 [CONFerence of Rabbinical Judges, i979], 68-70.

107 Id. at 70 .

Io8 Id. 
The problem came up also at the Conference of Rabbinical Judges held in I980, where again Rabbi Uriah explained that civil courts coerced husbands to grant gittin unlawfully by awarding high spousal support to their wives, and that they did so on purpose to speed up the granting of the get. ${ }^{109}$ Rabbi Moshe Yosef Miletzki, from the Jerusalem Rabbinical Court, took an even more extreme stand, making statements reminiscent of the ones we have heard about the need to revoke the prenuptial agreement as a condition for arranging a get. ${ }^{\mathrm{I}}{ }^{\mathrm{IO}} \mathrm{He}$ stated that his panel does not arrange a divorce before the woman brings a certificate from the civil court that her claim there has been closed, "otherwise there is a fear of coerced get because as long as he does not grant the get he is obligated to pay the high spousal support."

A range of rabbinical judges have ruled similarly. According to the Supreme Rabbinical Court: "The rabbinical court should not allow women to collect high spousal support awarded by the district court, as the rabbinical court ruled that she deserves less than that, according to Torah law." II The Regional Rabbinical Court in Jerusalem handled a case in which the woman who was refused a get undertook to return to her husband the spousal support she was awarded in civil court if he agreed to grant her a get. $^{\mathrm{II}}{ }^{\mathrm{I}}$ According to the rabbinical judges, such undertaking is not helpful. This is what Rabbi Shmuel Shapira said, with the agreement of his two colleagues in the panel: "Imposing spousal support by the civil court, even if they pay money to the husband, is considered coercion." II3

Another example is the ruling issued in the late I970s by the Regional Rabbinical Court in Petah Tikva, published in a collection of rulings of the head of the court, Rabbi Shlomo Karelitz. ${ }^{\text {I } 4}$ In that case, the husband filed for divorce and made heavy accusations of infidelity against his wife. At the same time, he also made certain financial requirements a condition for granting the get. For the purposes of our discussion, the argument arises that filing for spousal support in civil court, under an agreement signed by the husband (this case resembles greatly the agreement that is the subject of this article), would make the get coerced, therefore the woman had no choice but to withdraw her claim for spousal support if she wanted to obtain the get. ${ }^{15}$ This is also the opinion of Rabbi Axelrod, from the Rabbinical Court of Haifa. ${ }^{\text {I } 6}$

But in time, this position has eroded, and it is almost not found any more in courts, despite the fact that the number of spousal support claims filed in civil court increased substantially. One of the rabbinical judges even wrote a ruling that describes the lenient views on which it is possible to rely in arranging the get when the woman was awarded high spousal support in civil court, and the husband claims that he cannot afford it and is being threatened by the Enforcement and Collection Authority. ${ }^{117}$

\footnotetext{
IO9 Kenes haDayanim, 5740 [CONFEREnCe of Rabbinical Judges, I980], 32.

I IO Id. at 32-33. Cf. supra text accompanying note 57.

I I File No. 37/I976, Supreme Rabbinical Court (Jerusalem), Io PDR, 26I, 262 (Isr.).

I I 2 File No. I993/224, District Rabbinical Court (Jerusalem), I6 PDR, 260. On page 26I it is stated that the divorce agreement determined "that the husband shall receive a large amount, which is equivalent to the spousal support he should have paid according to the ruling of the civil court to the end of her days."

II 3 Id. at 270.

i 4 Shlomo Karelitz, Mishpatei Shlomo, vol. 2, sec. I (A.I.S. Karelitz ed., 2009).

I 5 Id. at I3.

I 6 Gedaliahu Axelrod, Get sheNitan meHamat Mezonot beSkhum Gavoah [Get Granted Because of High Spousal Support], I SHURAT Hadin 238 (I994).

I 7 Itzhak Elmaliach, Haskamt haBa'al leGet Ekev Hiyuvo beMezonot Gevohim Al-Yedey Arka'ot [Consent of the Husband to the Get Granted Because of High Spousal Support Awarded by the Courts], 9 SHURAT HADIN 249 (2005).
} 
Even rabbinical judges who theoretically insist on describing this as a serious halakhic problem, do not refrain from arranging gittin despite spousal support awarded in civil court, and even if in the past it was their opinion not to arrange gittin under these circumstances. For example, Rabbi Dichovsky, whose opposition to the agreement we have seen above, writes in the same article about the agreement that in many cases the spousal support ruling of the civil court is contrary to halakha and imposes high payments on the husband, which raises concern for a coerced get. ${ }^{\text {I } 8}$ In the distant past Rabbi Dichovsky believed that spousal support the woman is awarded in civil court is robbery and that it affects the process of divorce. ${ }^{\text {I } 9}$ But he changed his mind, and no similar rulings can be found in the last years of his tenure. In a later article he even criticized rabbinical courts that have ruled in the past that a spousal support claim raises doubts about the validity of the get, and argued that "it is possible to arrange a get without fear, even if spousal support was awarded unlawfully or excessively." ${ }^{2} 20$

Does, after all, spousal support awarded in civil court create a halakhic problem in arranging a get? How is it that in the past this issue came up again and again in rabbinical rulings and today it has almost been forgotten? I believe that in this case also the answer lies in the transition from a lechatchilah requirement to reliance on more lenient opinions (bediavad). In this case, it is possible to support the explanation by statistical data showing that in the past the civil courts struggled with this phenomenon, but at some point they decided to stop the struggle.

Researchers have already pointed out the dramatic change over time in the ratio between the number of spousal support claims filed in civil and in rabbinical courts. ${ }^{\mathrm{I2I}}$ In I963, rabbinical courts adjudicated more than eight times more spousal support claims than did the civil courts, ${ }^{\mathrm{I} 22}$ indicating that filing a claim in civil court was fairly unusual, and that the default option was to turn to the rabbinical court. By 1977 , the ratio fell to less than three to one, ${ }^{\mathrm{I} 23}$ and by $\mathrm{I} 993$ more claims were filed in civil court than in rabbinical court. ${ }^{\mathrm{I} 24}$ Since then, the gap has widened, and today the civil courts handle more than twice as many spousal support cases as rabbinical courts do. ${ }^{\mathrm{I} 25}$ In my opinion, in the past the strict approach served, apart from the understandable desire for divorce rulings to reflect the lechatchilah approach, also as a tool intended to preserve the authority of the rabbinical court and to deter couples from resorting to the civil courts, when the latter was still a relatively limited phenomenon. ${ }^{\mathrm{I} 26}$ But when the struggle against the rabbinical courts was decided, rabbinical judges understood that they will not be able to prevent the divorce in most claims submitted to them, and the strict position almost disappeared.

I 8 Dichovsky, supra note 52, at 280.

II9 See Asher Maoz, HaRabanut uBatei haDin: Bein Patish haHok leSadan haHalakha [The Rabbinate and the Rabbinical Courts: Between the Rock of the Law and the Hard Place of Halakha], I6-I7 SHENATON Hamishpat Haivri 289, 392-94 (I990-I99I) (specifically Maoz's extensive discussion of the file (Tel-Aviv) 6997/I980).

I 20 Shlomo Dichovsky, Darko Shel haRav Herzog beKefiyat Get [Rabbi Herzog's Method of Imposing Divorce], in Masua Leitzhak, Part I, 332, 339 (Shulamit Eliash et al. eds., 2009).

I2I Shochetman, supra note I02, at 406 n.I36; Ariel Rosen-Zvi, Batei haDin haRabaniyim, haHalakha vehaTsibur: Gesher Tsar Meod [Rabbinical Courts, Halakha, and the Public: A Very Narrow Bridge], 3 MisHPAT U-MimsHaL I73, I74-75 (I995) (offering explanations for this process).

I22 Central Bureau of Statistics, Legal Statistics I963, 26, 36.

I23 Central Bureau of Statistics, Legal Statistics I977, 40, 46.

I 24 Central Bureau of Statistics, Legal Statistics I993, 54, 63.

I 5 HALPERIN-KadDari, Horowitz, \& SHARvit, supra note ior.

I 26 In his opening remarks on the discussion concerning spousal support, Rabbi Ishayahu Goldschmidt described the prevalent situation in which child support payments were litigated in the civil courts whereas spousal support was generally determined in rabbinical court. CONFERENCE of RABBINICAL Judges, I979, supra note I06, at 68. 
Would a significant increase in the number of signatories of prenuptial agreements, who also use spousal support as a tool to pressure the recalcitrant husband, produce a similar phenomenon of change in the position of the rabbinical court?

\section{The Ma'is Lai ("Loathsome to Me") Ground in Rabbinical Courts}

The ma'is alai ground for divorce stands for the right of a woman who loathes her husband to get out of the marriage. The rabbinical court must assist her in achieving her goal, and in the distant past husbands have been coerced by whipping to grant a get to their wives. The literature on the ma'is alai ground is vast. ${ }^{127}$ At the Conference of Rabbinical Judges held in 2015, Rabbi Nachum Prover, a veteran rabbinical judge who had recently retired, pointed to a difficult problem he found in numerous rabbinical court rulings in recent years:

I see a breach in this topic. In many cases they determine that there is a ma'is alai claim and they also impose a divorce based on ma'is alai grounds. When I was at the Supreme Rabbinical Court for a whole year I saw many cases of get imposed on the ma'is alai grounds, but things are not as simple. ${ }^{\mathrm{I} 28}$

Rabbi Prover went on to explain why it is almost impossible to use this ground, not only to coerce a get, but even to impose one, expanding on the fact that this was the policy of the greatest rabbinical judges in the Israeli rabbinical courts in the past. In his opinion, present-day rabbinical judges must not "rule against the opinions of the great decisors that no get should be imposed when a matter as serious as coerced get" is at stake, and at best it is possible to recommend to the husband to divorce his wife who loathes him. ${ }^{\mathrm{I} 29}$ Another veteran rabbinical judge, Rabbi Binyamin Be'ery, joined Rabbi Prover and said,

There is something in particular that I saw recently, while I was at the Supreme Rabbinical Court. The clear halakha in Shulchan Aruch is that for "ma'is alai" we do not coerce and do not impose. The halakha has been eroded. Many judges easily impose for " $m a$ 'is alai," which is an obvious excuse. ${ }^{130}$

After one of the judges expressed his disagreement with the remarks of Rabbi Prover, the latter revealed the basic principles of his worldview: "I do not know in the poskim the phrase 'defunct marriage.' I do not know in the poskim the idea of 'she absolutely doesn't want him.' " ${ }_{\text {I3I }}$ In other words, Rabbi Prover understood well that the rise of the ma'is alai ground in rabbinical courts is influenced by Western concepts of "easy divorce," or at the request of the wife, a concept that in his opinion the halakha rejects. We can similarly understand the position of the opponents of the agreement.

The confrontation between the rabbinical judges who accept ma'is alai as a ground for divorce and those who reject it is clearly reflected also in the ruling of the Supreme Rabbinical Court. ${ }^{132}$ A woman left her husband because of his conduct, shortly after their marriage, and since then has

I 27 See generally, Bernard S. Jackson, Agunah: The Manchester Analysis I48-2 I4 (2OI I) (including the many sources cited in the footnotes).

I28 Nahum Prover, Te'anat Ma'is Alai [The Ma'is Alai Claim], in Yacobi \& Freimann, supra note 28 , at 226.

I $29 I d$. at $23 \mathrm{I}$.

I30 Id. at 234 .

I3I Id. at 235 .

I32 File No. 8I9I58/3, Supreme Rabbinical Court (Jerusalem) (May Iо, 20I I), tinyurl.com/zyl5n6p; see also, Westreich, supra note 88 . 
been living apart from him. The regional rabbinical court, and likewise the minority opinion in the Supreme Rabbinical Court, relied on ma'is alai as the main (if not the only) ground for divorce, to threaten the husband with jail if he refused to grant the divorce. The majority opinion in the Supreme Rabbinical Court, written by Rabbi Sherman, rejected this ruling outright and eliminated the threat of imprisonment. Rabbi Sherman showed at length that the regional rabbinical court deviated from the position that had prevailed for decades in rabbinical courts, according to which the ma'is alai ground, even in fairly obvious cases, does not lead to imposing a get. According to him, if the position of the regional rabbinical court is accepted, there will be cause to fear a coerced get. $^{\mathrm{I} 33}$

There is no doubt, therefore, that the prevailing policy in the past in rabbinical courts had been that the ma'is alai ground has almost no real weight. In the I950s, Rabbi Eliezer Yehuda Waldenberg raised the argument that the social reality of that time required discussing the possibility of relying on opinions that allow the imposition of a divorce when the woman claims $m a^{\prime}$ is alai. ${ }^{134}$ Rabbi Waldenberg was aware of the concern with the coerced get, and therefore proposed economic pressure based on awarding spousal support to the wife (note the similarity to the present mechanism in the agreements). But Rabbi Elyashiv's response rejected this proposal outright, based on the strict views that fear a coerced get. As Reiner has shown, for Rabbi Elyashiv arguments about problematic reality were not a consideration to be taken into account in showing lenience in halakhic rulings. ${ }^{\mathrm{I}} 35$ In other words, as we have seen above, Rabbi Elyashiv's position in this matter, as well as in others, was that we should not retreat from the strict lechatchilab policy when it comes to fear of coerced get. This position guided rabbinical courts for many years, and Rabbis Prover and Sherman naturally reference it.

Still, it appears that something has changed in recent years. More and more rabbinical judges consider seriously the $m a^{\prime}$ is alai ground and use it, including relying on it to impose sanctions on recalcitrant husbands. Several researchers have already pointed out this change, which is reflected in a number of verdicts. ${ }^{136}$ The same transpires from the detailed article of one of the rabbinical judges who tried to justify the position that regards the use of the ma'is alai ground positively. ${ }^{\mathrm{I} 37}$

What caused this change? Naturally, rabbinical judges try to present their rulings as continuing the rulings of the past, and almost never present their rulings as based on a social perception that differs from that of their predecessors. But it is quite clear that the increase in the use of ma'is alai does not stem from the discovery of halakhic sources that were not known before, but from the

I33 Here as well, it may not be possible to disconnect Rabbi Sherman's halakhic opinion from his ideological position, according to which Jewish law does not recognize the concept of "defunct marriage," an approach that he points out originates in legal systems alien to the halakha. See, e.g., Westreich, supra note 88, at I94-95.

I34 About this proposal and Rabbi Elyashiv's response, see Reiner, supra note 8, at 272-75.

I35 Id. at 276.

I36 Amihai Radzyner, Devar haMa'arekhet [Editorial], 36 HADIN VeHADAYAN (20I4), tinyurl.com/jrduonr; WeSTREICH, supra note 84 , at 3 I (identifying the use of ma'is alai with an increase in the perception of the "defunct marriage" in some of the rabbinical courts); Rachel Levmore, TEMUROT BeOlam PesiKat Batei HaDin haRabaniyim haMamlakhtiyim: Mehkar Hilkhati veNituah Shel Pesikot Batei haDin haRabaniyim beInyan GERUSHIN [The Changed Universe of Rulings of the Israeli Rabbinical Courts: An Halakhic and Analytical Study of the Rabbinical Courts Regarding Divorce] (2010) (unpublished Ph.D. dissertation, Bar-Ilan University), at 202-36.

I37 Yehudah Ya'ir Ben Menachem, “vaTenaheg Et Benotay kiShuuyot Herev?!” Al Pesikat Batei haDin haRabaniyim beTeanat Ma'is Alai beAmtala Mevoreret ["And You Have Carried Away My Daughters as Though Captives of the Sword!?" About the Decisions of the Rabbinical Courts in Relation to the Claim of "He Disgusts Me" as a Ground for Divorce], 6-7 Mishpaha BaMishpat [The Family IN Law] 2I7 (20I3-I4). It is easy to see that almost all the rulings he cites to show the use of ma'is alai have been issued in recent years. 
notion that there are cases in which a woman cannot be forced to live with her husband. Perhaps in the past such coercion imposed on women would be acceptable, but today large portions of society are not prepared to accept it. It is for this reason that opponents of the new trend focused on the rejection of the idea of "defunct marriage." More and more rabbinical judges believe that when it is clear that "married life reached its end, there is no point in trying to artificially resuscitate dead bodies." ${ }_{3} 8$ The rabbinical court can use the ma'is alai ground, which reflects the unwillingness of the wife to continue life in common, as a tool for ending the marriage. In other words, almost certainly the change in Israeli society and its attitude toward get refusal are causing many rabbinical judges to reconsider the approaches that were prevalent in the past, and to seek a more lenient halakhic position, moving from a strict lechatchilah approach to a more lenient one, bediavad. ${ }^{\text {I39 }}$

It is possible, therefore, that a similar change will happen in the attitude of rabbinical judges toward the agreements, especially as more and more couples express, by signing them, their view that one spouse should never have the right to prevent a divorce if the other spouse desires it. ${ }^{\mathrm{I} 4 \mathrm{O}}$

\section{CONCLUSION}

Israeli rabbinical judges claim that their court has priority over rabbinical courts abroad for being a state court, which allows it to demand that litigants appear before it and to apply sanctions against recalcitrant husbands. ${ }^{\mathrm{I} 4 \mathrm{I}}$ American rabbis also admit that the Israeli legal situation is better both halakhically $\mathrm{y}^{\mathrm{I} 2}$ and from the point of view of the ability of the court to help agunot. ${ }^{\mathrm{I} 43}$ Indeed, the unique status of the rabbinical court in Israel has resulted in legislation that grants its jurisdiction also over Jews who are not citizens of Israel, in order to help women denied a divorce from abroad whom their local rabbinical court cannot help. ${ }^{144}$

But are the chances of women refused get in Israel to escape their predicament always better than those of their American counterparts? Probably not. Quite likely, if the latter do not hold an agreement, the answer is affirmative. But if they do, their situation seems definitely better than that of Israeli women. The likelihood of Israeli women being at a disadvantage is even higher for those who do not resort to a "classic" divorce ground against the husband, which obligates him to

I38 From File No. 856035/I District Rabbinical Court (Haifa), (July 4, 20I2), tinyurl.com/z7dr84m. See also Westreich, supra note 84 , at $86-87$.

I39 Similarly to ma'is alai, another ground in the sources that imposes a divorce in cases of prolonged separation, a topic mentioned in Westreich, supra note 88. The authors cited there related this ground to the change in approach of rabbinical courts with respect to the "defunct marriage." One of the rabbinical judges even tried to explain why this ground has not been used until recently. See File No. 940783/13 District Rabbinical Court (Haifa), (Nov. 30, 2015), tinyurl.com/z4nels3.

I40 Cf. supra text accompanying note 84. Rabbi Bakshi Doron, former president of the Supreme Rabbinical Court, also pointed to the change in the reality of Israeli society as a factor to take into consideration, supra note 70. See generally Eliyahu Bakshi-Doron, Hok Nissuin veGerushin: haYotse Sekharo beHefsedo? [Marriage and Divorce Law: Causes More Harm than Good?], 25 Techumin 99 (2005). Rabbi Doron makes a more radical statement, arguing that in the current reality in Israel, it is halakhically preferable not to obligate by law couples to marry halakhically.

I4I Amihai Radzyner, Beit haDin haRabani Bein Bagats leBadats: Ma'amadam haHilkhati Shel Batei haDin veHashpaat Pesikato Shel Beit haMishpat haElyon Alav [The Halakhic Status of the Israeli Official Rabbinical Courts, and the Influence of the Israeli Supreme Court's Decisions on Them], I3 MishPaT U-Mimshal 27I, 290-96 (20II).

I42 Supra notes $8 \mathrm{I}-82$.

I43 BROYDE, supra note 74 , at 49-54.

I44 EINHORN, supra note IOO, at I7I, I93, 21 5; see also BROYDE, supra note 74, at 53-54. 
grant a get. ${ }^{\mathrm{I}} 45$ Even if such a ground is available to them, in many cases they obtain the get faster than their Israeli counterparts who have an identical ground available to them, because the agreement is activated immediately and automatically, and does not require a judicial verdict imposing a divorce (as well as sanctions)-decisions that can take years. ${ }^{146}$ Furthermore, American Jewish women who hold an agreement know in advance the policy of the rabbinical court that will arrange their divorce, which is not possible in Israel. ${ }^{\mathrm{I}} \mathrm{T}$ The answer to opening question of this paragraph is more complex that usually claimed.

There is no doubt that state rabbinical courts have advantages. But the argument should be raised that the case of divorce suggests that state sponsorship also carries the potential for conservative and strict attitudes; by contrast, in the Diaspora, a reality that includes the existence of a civil court leads to halakhic dynamism and solutions to the plight of litigants.

We have also seen that the answer to the question "Who is an agunab" is not uniform. A woman who seeks to escape a "defunct marriage" and whose husband refuses to give her a divorce is defined as agunab by Beth Din of America judges. This is not necessarily the case in an Israeli rabbinical court, certainly if she does not have an additional ground. The question of this woman's right to get out of her marriage is at the root of the controversy between supporters of the agreement in Israel and its opponents, who consider this concept to reflect foreign and improper Western influences; perhaps in the United States it is necessary to accept it in the absence of an adequate alternative, but in Israel, the land of lechatchilah, it should be strongly opposed.

Is there nevertheless cause for optimism on the part of the advocates of the agreement in Israel? Maybe. In several areas, a strict policy, reflecting the halakhic lechatchilab position, which was prevalent in rabbinical courts, has changed over time, at least as far as many judges are concerned. The changes occurred as a result of the fact that ever larger portions of the Jewish community acted, for various reasons, contrary to the stated halakhic opinion of the rabbinical court. Having no choice, rabbinical judges were forced to internalize the new reality. Advocates of the Israeli agreements also seem to assume that a significant increase in the number of agreements that will be signed and exercised, will force rabbinical courts to abandon their strict positions of avoiding to arrange gittin. They invest considerable marketing efforts to this end. ${ }^{48}$ At the same time, these efforts elicit strong reactions, including the statements and articles we cited in this article. Who will prevail? Will the status of the Israeli agreement approach that of its American counterpart? Only time will tell.

I45 Although Israeli law allows the rabbinical court to impose sanctions as part of every divorce ruling, THE RABBINICAL COURTS LAW, supra note $49, \mathbb{I}(\mathrm{b})$, the prevailing opinion in rabbinical courts in Israel, albeit with exceptions, is that no sanctions should be imposed for rulings that fall short of imposing the get. See Halperin-Kaddari \& Adelstein-ZeKback, supra note 50, at 32-33. Therefore, there are many situations in which the agreement would be activated in the United States, but in the parallel case in Israel, no sanction is imposed.

I46 For data from the rabbinical courts administration concerning the time that elapses from the filing of the claim until a ruling imposing a get and sanctions, see Halperin-Kaddari, Horowitz \& Sharvit, supra note IOI, at $85-$ 89. In more than 40 percent of cases it is over a year or more.

I47 As we have seen, the controversy between the rabbinical judges extends both to the question of the grounds for imposing a get and to the question of whether the sanctions allowed under Israeli law are halakhically valid. See, e.g., supra notes 50 and 88 ).

I 48 For example, the cooperation of Tzohar with the Israel Bar Association, Heskem Kedam-Nissuin leMeni'at Aginut - Hazmana leErev haHashaka [Prenuptial Agreement to Prevent Aginut - Invitation to the Launch Evening], IsRael Bar Association (Feb. 24, 20I 5), tinyurl.com/hlsehgs, and the tremendous marketing campaign for the agreement that Tzohar is conducting on the Internet. The Magic Touch, TzoHAR, http://tinyurl.com/ kmnj6lg (last visited May I4, 20I8). 